\title{
Coregulation of Natively Expressed Pertussis Toxin-Sensitive Muscarinic Receptors with G-Protein- Activated Potassium Channels
}

\author{
Sinead M. Clancy, ${ }^{1}$ Stephanie B. Boyer, ${ }^{1,2}$ and Paul A. Slesinger ${ }^{1,2}$ \\ ${ }^{1}$ Peptide Biology Laboratory, The Salk Institute for Biological Studies, La Jolla, California 92037, and ${ }^{2}$ Department of Neurosciences, University of \\ California, San Diego, La Jolla, California 92093
}

\begin{abstract}
Many inhibitory neurotransmitters in the brain activate Kir3 channels by stimulating pertussis toxin (PTX)-sensitive G-protein-coupled receptors. Here, we investigated the regulation of native muscarinic receptors and Kir3 channels expressed in NGF-differentiated PC12 cells, which are similar to sympathetic neurons. Quantitative reverse transcription-PCR and immunocytochemistry revealed that NGF treatment significantly upregulated mRNA and protein for $\mathrm{m}_{2}$ muscarinic receptors, PTX-sensitive G $\alpha_{\mathrm{o}} \mathrm{G}$-proteins, and Kir3.2c channels. Surprisingly, these upregulated muscarinic receptor/Kir3 signaling complexes were functionally silent. Ectopic expression of $\mathrm{m}_{2}$ muscarinic receptors or Kir3.2c channels was unable to produce muscarinic receptor-activated Kir3 currents with oxotremorine. Remarkably, pretreatment with muscarinic $\left(\mathrm{m}_{2} / \mathrm{m}_{4}\right)$ receptor antagonists resulted in robust oxotremorine-activated Kir3 currents. Thus, sustained cholinergic stimulation of natively expressed $\mathrm{m}_{2} / \mathrm{m}_{4}$ muscarinic receptors controlled cell surface expression and functional coupling of both receptors and Kir3 channels. This new pathway for controlling Kir3 signaling could help limit the potential harmful effects of excessive Kir3 activity in the brain.
\end{abstract}

Key words: Kir3; NGF; heterologous regulation; muscarinic GPCR; complex; pertussis toxin

\section{Introduction}

Activation of G-protein-coupled receptors (GPCRs) with neurotransmitters, such as acetylcholine and GABA, opens G-proteingated inwardly rectifying potassium channels (Kir3; GIRK) and produces slow inhibitory potentials (Lüscher et al., 1997). Kir3 channel activity has been implicated in drug addiction (Morgan et al., 2003; Cruz et al., 2004), in preventing excessive neuronal excitability (Signorini et al., 1997), and in influencing pain thresholds (Mitrovic et al., 2003). Overexpression of mutant Kir3.2 channels, however, can increase susceptibility to toxininduced cell death (Chung et al., 2005). Although one study has demonstrated that electroconvulsive shock increases the mRNA for Kir3 channels (Pei et al., 1999), the regulation of the Kir3 transcripts and protein under physiological conditions is poorly understood.

\footnotetext{
Received Nov. 27, 2006; revised April 27, 2007; accepted May 2, 2007.

This work was supported by the McKnight Endowment for Neuroscience, the Hearst Endowment Foundation, and National Institute of Neurological Disorders and Stroke/National Institutes of Health Grant R01-NS37682. We thank M. Baker and L. Ouyang at the Salk Institute sequencing facility for all advice and expert technical assistance relating to the qRT-PCR studies; advice provided by I. Hovata (Salk Institute) was greatly appreciated. We thank Dr. I. Verma and M. Schmitt for the use of the confocal microscope, Dr. M. Montminy for the PC12 cell line, K.-F. Suen for helpful discussions and for engineering the HA-epitope into Kir3.2c, and Dr. T. Jegla, Dr. C. Lüscher, and members of the Slesinger laboratory for their helpful comments on this manuscript.

Correspondence should be addressed to Paul A. Slesinger, Peptide Biology Laboratory, The Salk Institute for Biological Studies, La Jolla, CA 92037. E-mail: slesinger@salk.edu.

S. M. Clancy's present address: The Scripps Research Institute, Department of Biochemistry, 10550 North Torrey Pines Road, Institute for Childhood and Neglected Diseases 206, La Jolla, CA 92037.

DOI:10.1523/JNEUROSCI.1190-07.2007

Copyright $\odot 2007$ Society for Neuroscience $\quad$ 0270-6474/07/276388-12\$15.00/0
}

Four Kir3 channel subunits (Kir3.1-Kir3.4) have been identified in mammals (Dascal, 1997). Kir3.1 must coassemble with Kir3.2, Kir3.3, or Kir3.4 to produce functional channels (Hedin et al., 1996; Kennedy et al., 1996; Slesinger et al., 1996; Jelacic et al., 1999). In neurons, three different splice variants of Kir3.2 (Kir3.2a, Kir3.2b, and Kir3.2c) channels exist (Isomoto et al., 1997), each splice variant can form homotetramers in heterologous expression systems (Slesinger et al., 1996) and neurons (Inanobe et al., 1999b). Kir3 channels are activated via $G \beta \gamma$ dimers released from pertussis toxin (PTX)-sensitive $\left(\mathrm{G} \alpha_{\mathrm{i}} / \mathrm{G} \alpha_{\mathrm{o}}\right)$ G-proteins (Logothetis et al., 1987; Reuveny et al., 1994; Rishal et al., 2003; Finley et al., 2004). Stimulation of receptors that couple to PTX-insensitive G-proteins (e.g., $\mathrm{G} \alpha_{\mathrm{q}}$ and $\mathrm{G} \alpha_{\mathrm{s}}$ ), conversely, do not activate Kir3 channels (Yamada et al., 1998). The direct interaction of $\mathrm{G} \alpha_{\mathrm{i} / \mathrm{o}}$ subunits with Kir3 channels may be important for establishing specific PTX-sensitive GPCR/Kir3 signaling pathways (Slesinger et al., 1995; Ivanina et al., 2004; Clancy et al., 2005).

We hypothesize that Kir3 channels, PTX-sensitive G-proteins, and GPCRs (which we refer to as a "GPCR/Kir3 signaling complex") might be subject to a similar regulatory pathway. In addition, regulator of G-protein signaling proteins may also have a role in forming a GPCR/Kir3 signaling complex (Jaen and Doupnik, 2006; Fowler et al., 2007). Previous studies have examined GPCR/Kir3 signaling complexes in heterologous expression systems, in which proteins are ectopically overexpressed. Direct evidence demonstrating the regulation of a natively expressed GPCR/Kir3 signaling complex is lacking. Here, we used rat pheo- 
chromocytoma PC12 cells, which differentiate into sympatheticlike neurons in the presence of nerve growth factor (NGF) (Dichter et al., 1977; Greene and Tischler, 1982). PTX-sensitive G-protein subunits $\mathrm{G} \alpha_{\mathrm{o}}$ and $\mathrm{G} \alpha_{\mathrm{i} 2}$, as well as $\mathrm{G} \beta \gamma$ dimers are upregulated during NGF-mediated differentiation (Asano et al., 1989). Conversely, PTX-insensitive $\mathrm{G} \alpha_{\text {s }}$ subunits do not appear to be significantly affected (Andreopoulos et al., 1995). Whether NGF-mediated treatment changes Kir3 expression in PC12 cells is unknown. Using a combination of quantitative reverse transcription-PCR (qRT-PCR), immunocytochemistry, and whole-cell electrophysiology, we established that NGF upregulates a PTX-sensitive $m_{2}$ receptor $\left(m_{2} R\right) /$ Kir3.2 signaling complex. Surprisingly, muscarinic receptor activity appears to control the cell membrane expression of both muscarinic receptors and Kir3.2 channels. In addition to other pathways for regulating Kir3 activity, such as changes in phosphatidylinositol-4, bisphosphate levels (Kobrinsky et al., 2000) or regulators of G-protein signaling activity (Chuang et al., 1998; Mutneja et al., 2005), coregulation of muscarinic receptors and Kir3.2 channels provides a mechanism for regulating cell surface levels of muscarinic receptor/ Kir3.2 signaling complexes and thus Kir3.2 channel activation.

\section{Materials and Methods}

Cell culture and molecular biology. PC12 cells were kindly provided by $\mathrm{Dr}$ M. Montminy (Salk Institute for Biological Studies, La Jolla, CA). Cells were maintained in DMEM supplemented with fetal bovine serum (FBS) $(5 \%)$ and horse serum (HS) (10\%) $\left(\mathrm{DMEM}^{+}\right.$; Invitrogen, Carlsbad, $\mathrm{CA})$, in a humidified $37^{\circ} \mathrm{C}$ incubator with $95 \%$ air $/ 5 \% \mathrm{CO}_{2}$. NGF $(50$ $\mathrm{ng} / \mathrm{ml}$; Sigma, St. Louis, MO) differentiated PC12 cells were maintained in DMEM supplemented with NGF only (no FBS or HS) for 7-8 d, with regular medium changes every $24 \mathrm{~h}$. For electrophysiological recordings and immunocytochemistry, cells were plated onto $12 \mathrm{~mm}$ glass coverslips (Warner Instruments, Hamden, CT) coated with poly-D-lysine (20 $\mathrm{mg} / \mathrm{ml}$; Sigma) and collagen ( $100 \mathrm{mg} / \mathrm{ml}$; BD Biosciences, Franklin lakes, $\mathrm{NJ}$ ) in 24-well plates. For surface expression studies, HA-Kir3.2c was used, which contains hemagglutinin (HA) epitope inserted between I126 and E127. For total internal reflection fluorescence (TIRF) experiments, cells were plated on $35 \mathrm{~mm}$ glass-bottom culture dishes (MatTek, Ashland, MA) and coated as described above. The $\mathrm{m}_{2}$ muscarinic receptor was fused to cyan fluorescent protein (CFP) $\left(\mathrm{m}_{2}-\mathrm{CFP}\right)$ by engineering a $X h o$ site and Kozak sequence (GCCACC) $5^{\prime}$ to the start codon of $\mathrm{m}_{2}$ and a HindIII site before the stop codon using PCR and then subcloned into pECFP-N1 (Clontech, Mountain View, CA). Five day NGFdifferentiated PC12 cells were transfected with HA-Kir3.2c $(1 \mu \mathrm{g})$, GABA $_{\mathrm{B}} \mathrm{R} 1 / \mathrm{R} 2$ subunits ( $1 \mu \mathrm{g}$ each), $\mathrm{m}_{2} \mathrm{R}(1 \mu \mathrm{g})$, and/or $\mathrm{m}_{2} \mathrm{R}-\mathrm{CFP}(4$ $\mu \mathrm{g}) \mathrm{cDNA}$ using Lipofectamine 2000 (Invitrogen) and cultured for an additional $48 \mathrm{~h}$ before subsequent analysis.

RNA isolation and $q R T-P C R$. PC12 cells were plated onto $100 \mathrm{~mm}$ Petri dishes at a density of $\sim 5 \times 10^{6}$ cells per plate before NGF treatment. Total RNA was extracted from whole rat brain, undifferentiated, and NGF-differentiated (7-8 d) PC12 cells using the RNeasy mini kit, according to the instructions of the manufacturer (Qiagen, Valencia, CA). RNA was resuspended in PCR-grade DEPC-treated water (Invitrogen) and treated with DNase I (Invitrogen), and the concentration was calculated by $\mathrm{A}_{260}$ measurement. The integrity of the RNA was also further checked by $1 \%$ RNA gel electrophoresis; only RNA preparations with two clear sharp ribosomal bands were used in subsequent experiments. Firststrand cDNA was synthesized from $500 \mathrm{ng}$ of each RNA sample, using $0.01 \mathrm{~m}$ DTT, $0.5 \mathrm{~mm}$ each dNTP, $0.5 \mu \mathrm{g}$ of oligo-dT primer, $40 \mathrm{U}$ of RNaseOUT ribonuclease inhibitor and $200 \mathrm{U}$ of SuperscriptIII reverse transcriptase (Invitrogen). Triplicate RT reactions were performed, along with an additional reaction in which the reverse transcriptase enzyme was omitted to allow for assessment of genomic DNA contamination in each sample.

qRT-PCR was performed in the Salk Institute qRT-PCR facility using SYBR green PCR master mix (PE Biosystems, Foster City, CA) for each cDNA sample in a 96-well plate format. All plates contained a no- template and reverse transcriptase negative control. Standards were performed on each plate using known dilutions of rat brain genomic DNA for each gene analyzed. All genes were analyzed in triplicate, and a mean value was calculated; values were subsequently normalized to $\beta$-actin levels for each cDNA sample. Importantly, PC12 cell $\beta$-actin expression was not effected by NGF treatment, as had similarly been demonstrated previously (Lee et al., 1997). Detection of the PCR product was monitored by measuring the increase in fluorescence caused by the binding of SYBR green dye to the double-stranded DNA product using the ABI PRISM 7700 sequence detection system (PerkinElmer, Waltham, MA). Gene expression changes between control and NGF-treated groups were analyzed by determining the mean \pm SEM for three to four separate RNA preparations. Statistical significance was determined by Student's $t$ test for paired comparisons, and significance was taken as $p<0.05$. Data are presented as gene expression relative to $\beta$-actin expression (relative expression). The fold change in gene expression was determined dividing the mean value for NGF-differentiated PC12 cells by the value for undifferentiated PC12 cells.

Sequences of the selected genes were obtained from the genome sequence database website using the gene accession numbers. Primers were designed using Primer Express 1.5 software (PE Biosystems) to generate short amplicons. Primer sequences are indicated in supplemental Table A (available at www.jneurosci.org as supplemental material). The primers for Kir3.2c will also detect Kir3.2d, which is not expected to be expressed in neurons (Inanobe et al., 1999a).

Western blot analysis. PC12 cells were plated at density of $\sim 5 \times 10^{6}$ cells per $100 \mathrm{~mm}$ Petri dish. Seven day NGF-treated and control nontreated PC12 cells were washed once in ice-cold PBS. Homogenization buffer ( $2 \mathrm{ml}$ ) containing $10 \mathrm{~mm}$ Tris- $\mathrm{HCl}, \mathrm{pH}$ 7.4, $320 \mathrm{~mm}$ sucrose, and a protease inhibitor cocktail (Calbiochem, San Diego, CA) was added to each Petri dish on ice $\left(4^{\circ} \mathrm{C}\right)$. Cells were removed with a cell scraper and homogenized with an 18-guauge needle, passing the cell lysate through the needle 10 times on ice. Adult mice brains were homogenized using a "Polytron" homogenizer (power 18) for two 10-15 s pulses on ice; a gap of 1 min was allowed between each pulse to ensure that sample remained cool. Lysates were centrifuged $(1000 \times g, 10 \mathrm{~min})$ at $4^{\circ} \mathrm{C}$, and the supernatants were collected on ice and quantified by SDS-PAGE and Coomassie blue protein gel stain (Pierce, Rockford, IL).

For Western blot analysis, proteins were transferred to nitrocellulose membranes (GE Healthcare, Little Chalfont, UK) and blocked with SuperBlock buffer (Pierce) for $1 \mathrm{~h}$. Subsequently, blots were exposed to primary anti-Kir3.1 (1:200; AB5198; Millipore, Billerica, MA) or antiKir3.2 (1:200; APC-006; Alomone Labs, Jerusalem, Israel) antibodies for $1 \mathrm{~h}$, followed by $1 \mathrm{~h}$ in chicken anti-rabbit secondary antibody (1:1000; Santa Cruz Biotechnology, Santa Cruz, CA) at room temperature. Membranes were developed with Supersignal ECL (Pierce), were stripped with Western blot stripping buffer (Pierce), and were reprobed with anti- $\beta$ actin (1:1000; sc-47778; Santa Cruz Biotechnology) to ensure equal protein loading. Westerns analysis was performed three separate times, yielding similar results.

Pharmacology. For some studies, PC12 cells were treated with the nonselective muscarinic receptor antagonist atropine sulfate $(100 \mu \mathrm{M}$; Sigma) for $2 \mathrm{~h}$ at $37^{\circ} \mathrm{C}$ after $7 \mathrm{~d} \mathrm{NGF}$ treatment. To investigate the muscarinic receptor selectivity, the selective $\mathrm{m}_{2}$ muscarinic receptor antagonist AF-DX116 (11-[[2-[(diethylamino)methyl]-1-piperidinyl] acetyl]5, 11-dihydro-6H-pyrido[2,3-b][1,4]benzodiazepin-6-one; (100 nм; Tocris Bioscience, Ellisville, $\mathrm{MO}$ ), the selective $\mathrm{m}_{4}$ muscarinic receptor antagonist tropicamide (200 nM; Sigma), the selective $\mathrm{m}_{1}$ muscarinic receptor antagonist pirenzipine (100 nM; Sigma), and the selective $m_{3}$ muscarinic receptor antagonist 4-DAMP (10 nM; 1,1-dimethyl-4diphenylacetoxypiperidinium iodide; Tocris Bioscience) were used. Concentrations of muscarinic receptor antagonists used in this study were chosen according to previous studies extensively characterizing the pharmacological profile of each antagonist for the $\mathrm{m}_{2}$ muscarinic receptor (Waelbroeck et al., 1990), $\mathrm{m}_{1} / \mathrm{m}_{3}$ muscarinic receptor (Shi et al., 1999), and the $\mathrm{m}_{4}$ muscarinic receptor (Lazareno et al., 1993). After antagonist treatment, PC12 cells were washed in PBS for 15 min at room temperature before primary antibody exposure for imaging studies or in $20 \mathrm{~K}$ (see below) solution before whole-cell patch recordings. 
Immunocytochemistry. Control and NGF-differentiated PC12 cells were fixed with $1 \%$ paraformaldehyde for $30 \mathrm{~min}$; for anti-HA studies, $50 \%$ of the cells were permeabilized with $0.25 \%$ Triton X-100 (Sigma) in PBS for 10 min, whereas the remaining 50\% were treated with PBS only (nonpermeabilized). All cells were washed twice in PBS and blocked with 2\% IgG-free BSA (Fisher Scientific, Pittsburgh, PA) plus 2\% donkey serum (Invitrogen) in PBS for $1 \mathrm{~h}$ at room temperature. Cells were subsequently labeled with mouse monoclonal anti-HA antibody $(1.25 \mathrm{mg} /$ $\mathrm{ml}$, MMS-101P; Covance, Princeton, NJ), rabbit anti- $\mathrm{m}_{2}$ muscarinic receptor (1:250; AB5166; Millipore), mouse anti- $\mathrm{m}_{4}$ muscarinic receptor (1:250; MAB1576; Millipore), rabbit anti- $\mathrm{m}_{1}$ muscarinic receptor (1:200; AB51641; Millipore), G $\alpha_{\mathrm{o}}$ (1:400; sc-13532; Santa Cruz Biotechnology), rabbit anti-Kir3.2 (P8122; 1:200; Sigma), or rabbit anti-Kir3.1 (P7997; 1:200; Sigma) in blocking buffer for $2 \mathrm{~h}$ at room temperature. After extensive washing in PBS, cells were incubated in cyanine 3 (Сy3)conjugated donkey anti-mouse IgG or Cy3 donkey anti-rabbit IgG secondary antibody (1:200; Jackson ImmunoResearch, West Grove, PA), according to primary antibody host species, for $1 \mathrm{~h}$. After extensive washing, cells were mounted onto glass slides with 1,4diazabicyclo $(2,2,2)$ octane (DABCO) in glycerol (Slow Fade Light Antifade Kit; Invitrogen). Cells were imaged with a Zeiss (Oberkochen, Germany) LSM 5 PASCAL laser confocal microscope using a $63 \times$, oil immersion objective and excitation at $543 \mathrm{~nm}$. In addition, previous $1 \mathrm{~h}$ incubation of each muscarinic antibody with the respective control antigen confirmed receptor antibody specificity. To compare undifferentiated and differentiated PC12 cells, the same gain, pinhole, and exposure time were used, and the TIFF images were scaled to the same pixel range for publication. All imaging and immunocytochemical experiments were repeated at least three times in duplicate, yielding similar results.

Total internal reflectance fluorescence microscopy. TIRF microscopy was used to study surface expression of $\mathrm{m}_{2}$ muscarinic receptors. Throughthe-objective TIRF microscopy occurs when collimated laser light is offset to illuminate the back focal plane of the objective, which causes the laser light to arrive at the coverslip at an angle. When this angle is greater than the critical angle $(\theta)$, an evanescent wave of excitation light is produced at the interface between two media having different refractive indices, the glass coverslip, and media/cell membrane (Axelrod et al., 1983). The intensity of this evanescent wave falls off exponentially with distance above the interface, allowing selective imaging within $\sim 100 \mathrm{~nm}$ of the glass/medium interface (i.e., plasma membrane and submembrane regions). A Nikon (Tokyo, Japan) TE2000 microscope was equipped with a $60 \times$ oil-immersion TIRF objective (Nikon; 1.45 numerical aperture) and a solid-state DPSS $442 \mathrm{~nm}$ laser (model 85 BTL 010; Melles Griot, Carlsbad, CA), which could be adjusted manually for epifluorescence and TIRF. The Nikon filter cube contained a polychroic mirror with reflection bands at 440 and $510 \mathrm{~nm}$ and bandpasses at 475/30 and 560/60 nm (z442/514rpc; Chroma Technologies, Brattleboro, VT). No excitation filter was used. A CFP emission filter $(470 / 30 \mathrm{~nm})$ was placed in a filter wheel (Sutter Instruments, Novato, CA) and controlled by a Lambda 10-2 controller (Sutter Instruments). Images (16 bit) were acquired with a $12.5 \mathrm{MHz}$ Imago CCD camera (T.I.L.L. Photonics, Martinsried, Germany). The camera, laser shutters, and filter wheel were electronically controlled by TILLvisION software. Transfected cells were imaged first using epifluorescence (100 ms exposure time) and, after adjusting the laser, using TIRF (500 ms exposure) microscopy. Fluorescent intensity was analyzed using NIH ImageJ software. Background was first subtracted, then a region of interest was drawn around the entire cell (epifluorescence) or the footprint (TIRF), and the average fluorescent intensity (in arbitrary units) was measured.

Electrophysiology. Whole-cell patch-clamp technique (Hamill et al., 1981) was used to record macroscopic currents from control and NGFdifferentiated treated PC12 cells. Borosilicate glass electrodes (P6165T: Warner Instruments) were pulled on a Narashige (Hempstead, NY) puller and used without Sylgard and fire polishing. Electrodes had resistances of 5-7 M $\Omega$. Membrane currents were recorded with an Axopatch 200B (Molecular Devices, Sunnyvale, CA) amplifier at room temperature, filtered at $2 \mathrm{kHz}$, digitized at $5 \mathrm{kHz}$ with a Digidata 1320 interface (Molecular Devices), and stored on a laboratory computer. The intracellular pipette solution contained the following (in $\mathrm{mm}$ ): $130 \mathrm{KCl}, 20 \mathrm{NaCl}$,
5 EGTA, $2.56 \mathrm{~K}_{2} \mathrm{ATP}, 5.46 \mathrm{MgCl}_{2}$, and 10 HEPES, pH7.2 with $\mathrm{KOH}$. $\mathrm{Li}_{2} \mathrm{GTP}(300 \mu \mathrm{M}$; Sigma) was added fresh to the intracellular pipette solution. The external bath solution $(20 \mathrm{~K})$ contained the following (in $\mathrm{mm}$ ): $140 \mathrm{NaCl}, 20 \mathrm{KCl}, 0.5 \mathrm{CaCl}_{2}, 2 \mathrm{MgCl}_{2}$, and $10 \mathrm{HEPES}$, pH 7.2 with $\mathrm{NaOH} . \mathrm{BaCl}_{2}$ (1 mm; Sigma) was added directly to the $20 \mathrm{~K}$ solution. Oxotremorine methiodide (Oxo-M) (Sigma) was made up as a $1 \mathrm{~mm}$ stock and diluted (100 nM) on the day of experiment. SCH-23390 (Tocris Bioscience) was made as $3 \mathrm{~mm}$ stock and diluted to $30 \mu \mathrm{m}$. For ethanol activation, $100 \%$ ethanol was added to the $20 \mathrm{~K}$ solution to give a $200 \mathrm{~mm}$ final concentration (EtOH density of $0.7893 \mathrm{~g} / \mathrm{ml}$ ). A ramp voltage protocol $(-120$ to $+50 \mathrm{mV})$ or continuous voltage protocol was used to study Kir3 currents.

Analyses. Mean \pm SEM values are shown. For statistical analyses, Student's $t$ test $(p<0.05)$ was used for comparison between two groups. When appropriate, one-way ANOVA (Dunnett's post hoc, $p<0.05$ ) or one-way ANOVA on ranks (Tukey's post hoc, $p<0.05$ ) was used for comparison between multiple groups (SigmaStat 3.0; Systat Software, San Jose, CA).

\section{Results}

NGF selectively upregulates Kir3.2c channels and other essential proteins in the PTX-sensitive G-protein signaling pathway

Previous studies have demonstrated that PTX-sensitive G-protein subunits are upregulated in PC12 cells during NGFmediated differentiation (Asano et al., 1989). Because of the coupling of $\mathrm{G} \alpha_{\mathrm{o}}$ subunits with Kir3 channels (Leaney and Tinker, 2000; Ivanina et al., 2004; Clancy et al., 2005), we hypothesized that Kir3 channels may be upregulated in NGF-differentiated PC12 cells. To examine this, we used qRT-PCR, a very sensitive method for quantifying mRNA levels in living cells. Previous studies have demonstrated that $\sim 85 \%$ of PC12 cells differentiate with $>5 \mathrm{~d}$ NGF treatment, as measured by neurite outgrowth and formation of synaptic-like vesicles (Lee et al., 2005). To ensure that subsequent studies reflected a differentiated pool of cells, PC12 cells were exposed to NGF for at least $7 \mathrm{~d}$. After a $7 \mathrm{~d}$ treatment with NGF (50 ng/ml), we examined mRNA levels for different Kir3 channels using subunit-specific probes and rat brain mRNA as a positive control. Kir2.1, Kir3.1, Kir3.2a, Kir3.2b, Kir3.2c, Kir3.3, and Kir3.4 channel mRNA were all detected in rat brain, but only Kir2.1, Kir3.1, and the splice variant Kir3.2c mRNA were expressed in both the undifferentiated and NGF-differentiated PC12 cells (Fig. 1A,B). Of these channels, NGF treatment selectively increased the mRNA for Kir3.2c $(+5.2 \pm 1.2$-fold), whereas no significant change in mRNA levels was measured for Kir2.1 or Kir3.1 channels (Fig. 1A,C) mRNA. This finding suggests that NGF treatment leads to a selective increase in Kir3.2c gene expression.

We next investigated possible changes in mRNA levels for other proteins in the PTX-sensitive GPCR signaling pathway. Similar to previous studies (Asano et al., 1989), expression of the PTX-sensitive $\mathrm{G} \alpha_{\mathrm{o}}$ subunit increased in NGF-differentiated cells $(+9.5 \pm 3.18$-fold) (Fig. 1C). In contrast, we found that mRNA for PTX-sensitive $\mathrm{G} \alpha_{\mathrm{i} 3} \mathrm{G}$-protein was not significantly altered by NGF treatment (Fig. 1C), whereas the mRNA for the PTXinsensitive $\mathrm{G} \alpha$, subunit significantly decreased $(-2.9 \pm 0.53)$ (Fig. 1C). In agreement with previous studies (Andreopoulos et al., 1995), $\mathrm{G} \alpha$ s subunit expression was not significantly altered by NGF treatment (Fig. 1C). Thus, NGF treatment increased mRNA expression for both the Kir3.2c channel subunit and the PTXsensitive $\mathrm{G} \alpha_{\mathrm{o}} \mathrm{G}$-protein.

To further explore the regulation of the PTX-signaling complex by NGF, we used qRT-PCR to study the possible changes in gene expression for the muscarinic receptors. The PTX-sensitive G-protein-coupled $\mathrm{m}_{4}$ muscarinic receptor was shown previ- 

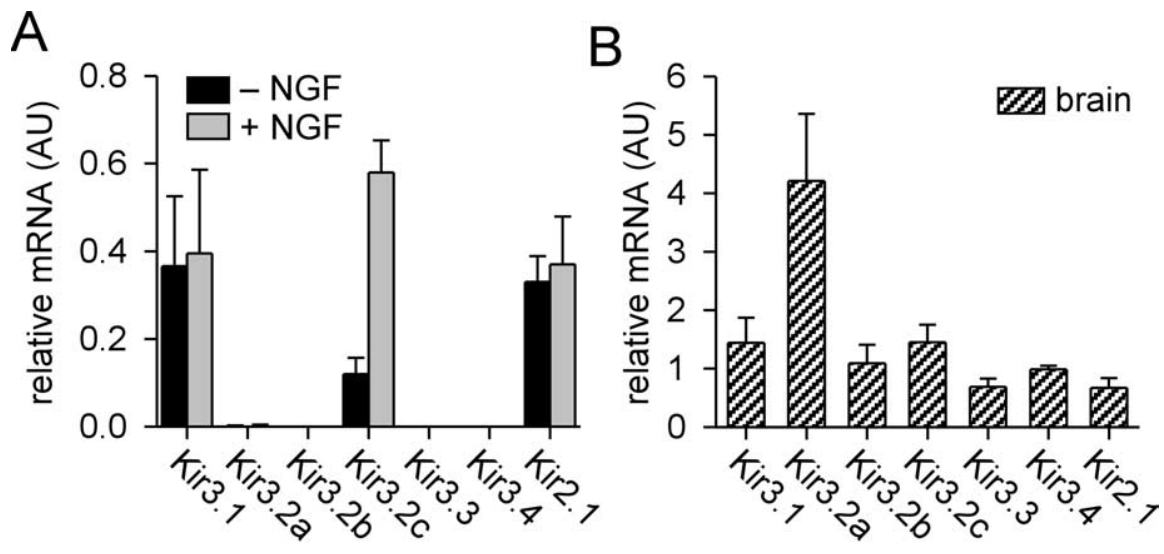

C

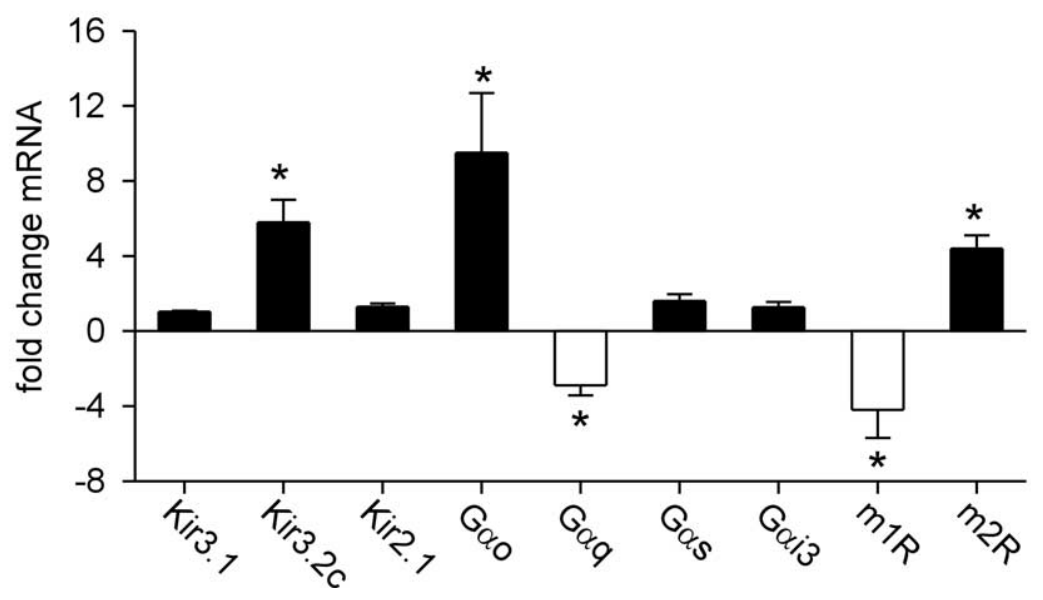

Figure 1. Quantitative increase in mRNA expression for $m_{2}$ muscarinic receptors, $G \alpha_{0} \mathrm{G}$-proteins, and the splice variant Kir3.2c. $A, B, B a r$ graphs show the average of several (3- 4 separate RNA preparations) experiments in which the levels of mRNA for the indicated Kir genes in control and NGF-differentiated PC12 cells were quantified using qRT-PCR. Control undifferentiated and NGF-differentiated PC12 cells $(\boldsymbol{A})$ and rat brain $(\boldsymbol{B})$. Kir3.2a, Kir3.2b, Kir3.3, and Kir3.4 mRNAs were detected in rat brain but were not evident in either control or NGF-differentiated PC12 cells. Kir3.1 and Kir2.1 mRNA levels were unchanged by NGF treatment. Levels of RNA were normalized to $\beta$-actin [arbitrary units (AU)]. C, Bar graph shows the fold change in mRNA produced by NGF for indicated genes. Genes required for Kir3 signaling, including $\mathrm{m}_{2}$ muscarinic receptor, $\mathrm{G} \alpha_{0} \mathrm{G}$-protein and Kir3.2c were significantly increased with NGF treatment, whereas mRNA for PTX-insensitive $G \alpha_{q}$ and the $m_{1} R$ were significantly decreased. Fold change in gene expression was determined by dividing the mean expression for each gene analyzed for NGF-treated cells by non-NGFtreated cells. Relative gene expression changes between control and NGF-treated groups were analyzed using the mean \pm SEM for three to four separate RNA preparations ( ${ }^{*} p<0.05$ ).

ously to be upregulated by NGF differentiation of PC12 cells (Lee and Malek, 1998). We additionally demonstrated that NGF also increased mRNA for the PTX-sensitive G-protein-coupled $\mathrm{m}_{2}$ muscarinic receptor $(+4.4 \pm 0.7$-fold $)$ but significantly decreased mRNA for the PTX- insensitive G-protein-coupled $\mathrm{m}_{1} \mathrm{R}$ $(-4.2 \pm 0.7$-fold) (Fig. 1C). Together, these findings demonstrate that NGF differentiation upregulates mRNA expression of Kir3.2c channel subunits, in addition to the selective increase of the PTX-sensitive G-protein signaling pathway $\left(m_{2} R, m_{4} R\right.$, $\left.\mathrm{G} \alpha_{\mathrm{o}}\right)$.

Although mRNA levels were significantly affected by NGF, it remained possible that changes at the protein level were unaltered by NGF-mediated differentiation. To examine this directly, we performed Western blot analysis to determine whether NGF $7 \mathrm{~d}$ treatment increased the expression of Kir3 channel protein. Whereas Kir3.1 channel protein changed little with NGF, the levels of Kir3.2 channel protein increased significantly in NGFdifferentiated PC12 cells (Fig. 2A). We then used immunocyto- chemistry and confocal microscopy to determine the intensity and pattern of protein expression throughout the cells. Similar to the Western analysis, Kir3.1 total protein expression was not greatly affected by $7 \mathrm{~d}$ NGF differentiation (Fig. $2 B, C)$. In contrast, the intensity of Kir3.2 immunoreactivity increased after NGF treatment (note that the channel is expressed predominantly in the soma of differentiated cells) (Fig. 2D,E). Thus, both qRTPCR and protein analysis indicated that Kir3.2c but not Kir3.1 channels are upregulated in NGF-differentiated PC12 cells.

We next determined the cell protein expression pattern for other proteins in the PTX-sensitive GPCR signaling pathway. Immunoreactivity for PTX-sensitive $\mathrm{G} \alpha_{\mathrm{o}}$ G-protein was also increased by NGF treatment, although to a lesser extent than Kir3.2: $\mathrm{G} \alpha_{\mathrm{o}}$ was expressed in both the neurites and soma (Fig. $2 F, G$ ). Both $\mathrm{m}_{2}$ and $\mathrm{m}_{4}$ muscarinic receptor immunoreactivity increased after NGF differentiation. Similar to Kir3.2 channels, the receptors appeared to be expressed predominantly in the cytoplasm and particularly around the nucleus (Fig. $2 H-K$ ). Immunoreactivity for the $\mathrm{m}_{1}$ muscarinic receptor, conversely, was reduced (Fig. $2 L, M$ ), consistent with the decrease in mRNA expression revealed by qRT-PCR analysis. Together, these data suggest a selective NGF-mediated upregulation of the PTXsensitive Kir3.2c channel signaling pathway and a decrease in the PTX-insensitive G-protein pathway.

\section{Absence of muscarinic receptor- activated Kir3.2 currents in NGF- differentiated PC12 cells}

The significant increase in the PTXsensitive G-protein/Kir3 channel signaling complex suggested that a large muscarinic-activated Kir3 current would be evident in NGF-differentiated PC12 cells. Whole-cell patchclamp recordings were used to examine this possibility in $7 \mathrm{~d}$ NGF-differentiated PC12 cells. Figure $3 A$ shows an example of a typical $7 \mathrm{~d}$ NGF-differentiated PC12 cell, with a multipolar soma and neurite extensions. Surprisingly, the muscarinic receptor agonist Oxo-M at 100 nm did not elicit a Kir3 channel response in $>50$ recordings from $7 \mathrm{~d}$ NGF-differentiated PC12 cells or undifferentiated cells (Table 1, Fig. 3B). In fact Oxo-M concentrations up to $100 \mu \mathrm{M}$ did not elicit a Kir3 channel response (data not shown; $n=4$ ). In addition, $200 \mathrm{~mm}$ ethanol (a direct activator of Kir3 channels) and $1 \mathrm{~mm} \mathrm{Ba}^{2+}$ (an inhibitor of Kir3) did not alter the basal currents (Table 1, Fig. 3B), suggesting that Kir3 channels were not expressed on the membrane surface. To attempt to rescue muscarinic receptor-activated Kir3 currents, 5 d NGFtreated PC12 cells were transiently transfected with $\mathrm{m}_{2}$ receptor cDNA (along with yellow fluorescent protein cDNA) and visualized by fluorescence. Whole-cell recordings, however, did not reveal detectable muscarinic receptor-activated currents or 
$\mathrm{Ba}^{2+}$-dependent basal currents in these transfected differentiated cells (Table 1, Fig. 3C). One possible explanation for this finding was that Kir3.2c and/or muscarinic receptors were tightly regulated and not expressed on the plasma membrane. To investigate this possibility, we examined the surface expression of Kir3.2 channels expressed in NGF-differentiated PC12 cells.

To determine the surface expression of Kir3.2c, we engineered an extracellular HA epitope for detecting proteins expressed on the surface (Fig. 3D). This tag does not interfere with Kir3.2a trafficking or $\mathrm{G} \beta \gamma$ activation (Finley et al., 2004). NGF-treated PC12 cells were transfected with HA-Kir3.2c on day 5 and then cultured in NGF for an additional $48 \mathrm{~h}(7 \mathrm{~d}$ treatment). Surprisingly, anti-HA immunocytochemistry with nonpermeabilized PC12 cells revealed little or no surface expression of HA-Kir3.2c (Fig. 3E). Permeabilized PC12 cells, conversely, showed robust immunostaining for HA-Kir3.2c, indicating successful transfection and expression (Fig. $3 F$ ). These data suggest that, although Kir3.2c channels are expressed in NGF-differentiated PC12 cells, maintenance of channels on the plasma membrane is somehow impaired, leading to the absence of muscarinic-activated endogenous Kir3 responses. Similarly, endogenous $\mathrm{m}_{2}$ and $\mathrm{m}_{4}$ muscarinic receptor immunoreactivity appeared to be predominantly in the cytoplasm of $7 \mathrm{~d}$ NGF-differentiated PC12 cells (Fig. 2H,I and $J, K$, respectively). Together, these studies suggest that, although the protein expression of the Kir3.2c channel and the muscarinic receptors $\left(\mathrm{m}_{2} \mathrm{R} / \mathrm{m}_{4} \mathrm{R}\right)$ are increased in NGF-differentiated cells, surface expression is unexpectedly low.

To determine whether endogenous Kir3 channels were capable of coupling to other GPCRs, we examined the effect of introducing the cDNA for the $G_{A B A} R 1$ and $R 2$ receptor subunits into the NGF differentiated cells. Application of the $\mathrm{GABA}_{\mathrm{B}}$ agonist baclofen (100 $\mu \mathrm{M})$ elicited inwardly rectifying $\mathrm{K}^{+}$currents in NGFdifferentiated PC12 cells (Table 1) (baclofen-induced current, $-19.8 \pm 4.0 \mathrm{pA} / \mathrm{pF} ; n=19)$. Thus, the upregulated Kir3.2 channels can functionally couple to a GPCR that couples to PTXsensitive G-proteins, suggesting a specific defect in the muscarinic receptor and Kir3.2 channel complex signaling pathway.

Atropine rescues muscarinic receptor and Kir3.2c expression and functional coupling on the plasma membrane

We next investigated whether the absence of measurable muscarinic receptor-mediated Kir3.2 currents in NGF-treated cells resulted from a receptor/channel complex that was endocytosed, immediately after surface expression. Recently, Bernard et al. (2003) found that muscarinic receptors were predominantly localized to the cytoplasm in neurons of a mouse mutant that con$20 \mu \mathrm{m}$.
anti-Kir3.1
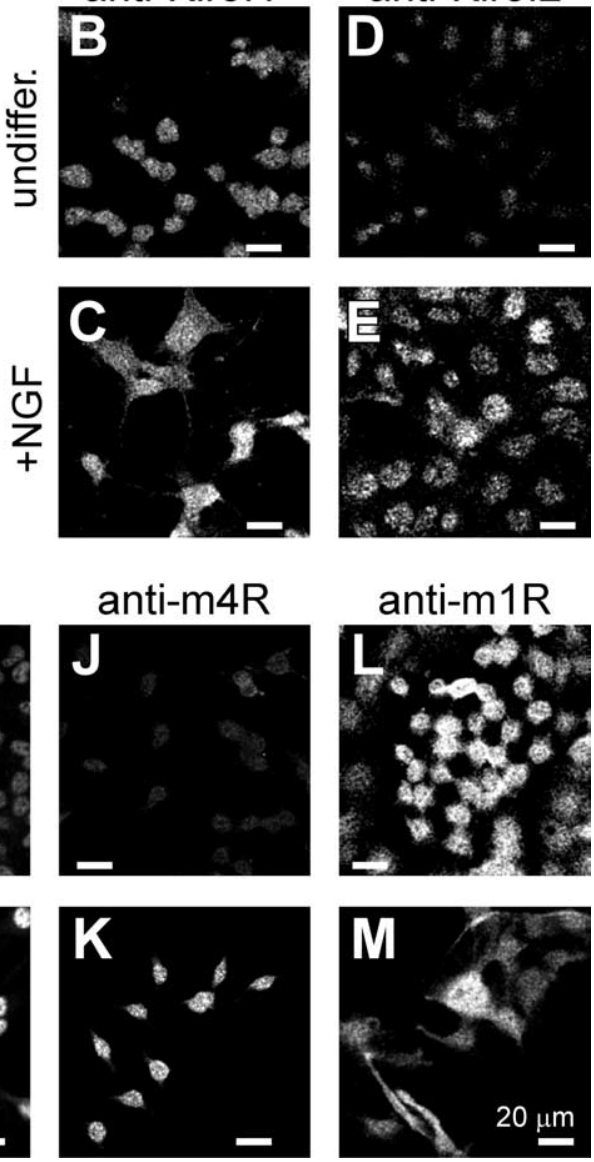

Figure 2. NGF-mediated increase in protein for Kir3.2 channels, $G \alpha_{0}$ subunits, and $m_{2} / m_{4}$ muscarinic receptors. Levels of protein for the indicated signaling molecules were studied by Western blot analysis and immunostaining in undifferentiated and ifferentiated PC12 cells. A, Western blot analysis demonstrates the NGF-mediated increase in Kir3.2 channel protein in immunoblot (IB) (bottom) shows equal protein for the PC12 cell lysates. Mouse brain lysate (brain) was loaded onto each gel to demonstrate the correct size protein band for each respective protein. $\boldsymbol{B}-\boldsymbol{M}$, Immunostaining and confocal imaging demonstrates that Kir3.1 protein shows little or no increase after NGF treatment $(\boldsymbol{B}, \boldsymbol{C})$; in contrast, Kir3.2 protein shows a significant increase in expression $(\boldsymbol{D}, \boldsymbol{E})$. To a lesser extent, PTX-sensitive $G \alpha_{0} G$-protein are increased after NGF treatment $(\boldsymbol{F}, \boldsymbol{G})$. Both $\mathrm{m}_{2}(\boldsymbol{H}, \boldsymbol{I})$ and $\mathrm{m}_{4}$ cytoplasmic and perinuclear. $\boldsymbol{L}, \boldsymbol{M}, \mathrm{m}_{1}$ muscarinic receptor immunoreactivity modestly decreases after NGF treatment. Scale bars,

tained elevated levels of acetylcholine. NGF-differentiated PC12 cells can synthesize and release acetylcholine (Greene and Rein, 1977), which could lead to elevated levels of acetylcholine. Bernard et al. (2003) found that exposing the neurons to a nonselective muscarinic receptor antagonist (atropine) prevented the translocation of endogenous muscarinic receptors from the cell surface to the cytoplasm. We therefore next investigated whether atropine treatment of $7 \mathrm{~d}$ NGF differentiated PC12 cells would rescue plasma membrane expression of muscarinic receptors and possibly Kir3 channels. Indeed, pretreatment of NGF differentiated PC1 2 cells for $2 \mathrm{~h}$ with atropine $(100 \mu \mathrm{M})$ "rescued" the surface expression of ectopically expressed HA-Kir3.2c. Prominent cell surface staining for HA-Kir3.2c is now evident in nonpermeabilized cells (Fig. $4 A$ ). We also examined the effect of atropine pretreatment on endogenous $\mathrm{m}_{2}$ muscarinic receptor and $\mathrm{m}_{4}$ muscarinic receptor expression patterns (Fig. $4 B, C$, respectively). Here, PC12 cells were permeabilized because the antibody recognizes an intracellular epitope on the receptor. In 
A

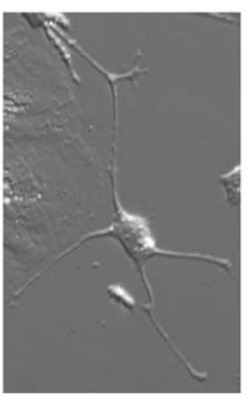

$\mathrm{B}$
$+\mathrm{NGF}$

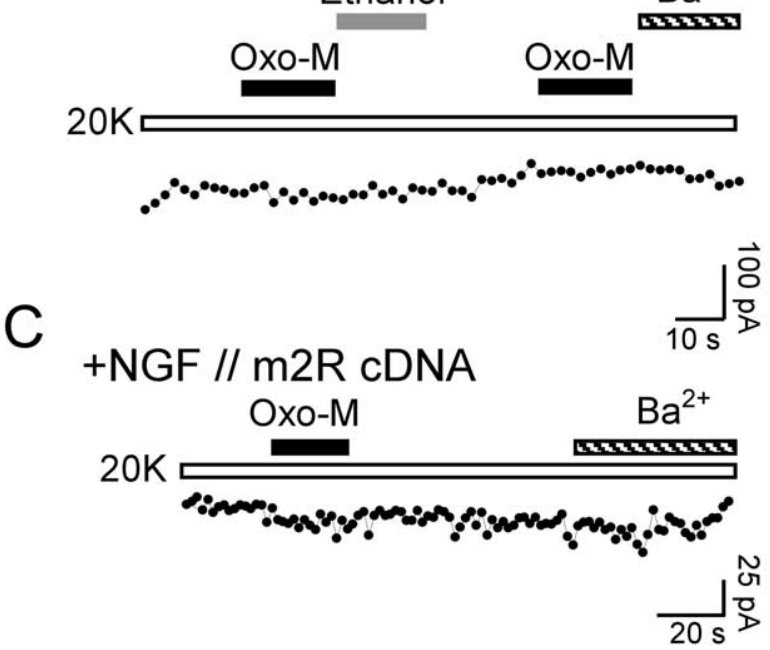

D

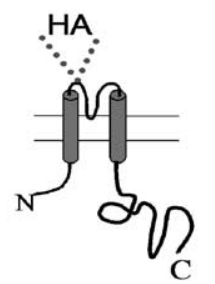

HA-Kir3.2c

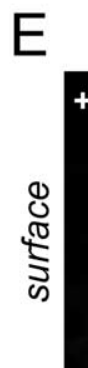

anti-HA

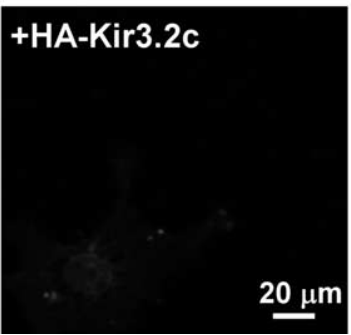

$\mathrm{F}$

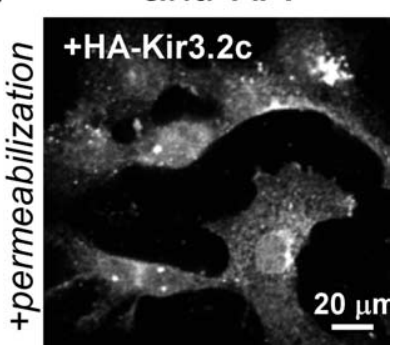

Figure 3. Upregulated $\mathrm{m}_{2}$ receptor/Kir3 channel complex is functionally silent in NGF-differentiated PC12 cells. $A$, Differential interference contrast (DIC) picture of a typical NGF-differentiated PC12 cell. $\boldsymbol{B}$, Representative example of an NGF-differentiated PC12 cell in which muscarinic receptor agonist $0 \times 0-M(100 \mathrm{~nm})$ or ethanol $(200 \mathrm{~mm})$ did not elicit a Kir3 channel response. The Kir3 channel inhibitor $\mathrm{Ba}^{2+}(1 \mathrm{~mm})$ demonstrated no detectable Kir3.2 basal currents $(n=30)$. Current was measured at $-120 \mathrm{mV}$ in voltage ramps and plotted as a function of time. C, Ectopic expression of $\mathrm{m}_{2}$ receptor did not rescue muscarinic receptor/Kir3 signaling complex. Five day NGF-treated $\mathrm{PC} 12$ cells were transfected with $\mathrm{m}_{2}$ muscarinic receptor CDNA (1 $\mu \mathrm{g})$ and whole-cell recordings made 2 d later. $0 \times 0-\mathrm{M}(100 \mathrm{~nm})$-activated or $\mathrm{Ba}^{2+}$-inhibited Kir3 currents were not observed. D, Schematic shows topology and placement of extracellular HA epitope into the p-loop of Kir3.2c. E, Immunostaining for HA demonstrates that HA-Kir3.2c is undetectable on the plasma membrane of NGF-differentiated cells. $\boldsymbol{F}$, Detergent permeabilized cells exhibit strong cytoplasmic anti-HA immunoreactivity, demonstrating predominantly intracellular expression of HA-Kir3.2C.

Table 1. Summary of Kir3 currents in PC12 cells

\begin{tabular}{|c|c|c|c|c|c|}
\hline NGF & Experimental condition & Agonist & $\begin{array}{l}\text { Current density } \\
(\mathrm{pA} / \mathrm{pF})\end{array}$ & $n$ & \% Kir3 response \\
\hline- & No treatment & $0 \times 0-M$ & $-0.29 \pm 0.06$ & 19 & $0 \%(0 / 19)$ \\
\hline+ & No treatment & $0 \times 0-M$ & $-0.21 \pm 0.02$ & 56 & $0 \%(0 / 56)$ \\
\hline+ & No treatment & Ethanol & $-0.19 \pm 0.04$ & 30 & $0 \%(0 / 30)$ \\
\hline+ & $+m_{2} R c D N A$ & Oxo-M & $-0.33 \pm 0.14$ & 4 & $0 \%(0 / 4)$ \\
\hline+ & $+\mathrm{GABA}_{\mathrm{B}} \mathrm{R} 1 / \mathrm{R} 2 \mathrm{CDNA}$ & Baclofen & $-19.8 \pm 4.0^{*}$ & 19 & $68 \%(13 / 19)$ \\
\hline+ & + Atropine antagonist & $0 \times 0-M$ & $-16.1 \pm 4.0^{*}$ & 43 & $65 \%(28 / 43)$ \\
\hline- & + Atropine antagonist & $0 \times 0-M$ & $-0.38 \pm 0.12$ & 19 & $0 \%(0 / 19)$ \\
\hline+ & +Atropine antagonist & Ethanol & $-38.8 \pm 6.7^{*}$ & 34 & $61 \%(21 / 34)$ \\
\hline+ & $+\mathrm{m}_{2} \mathrm{R}$ antagonist & $0 \times 0-M$ & $-31.4 \pm 13.8^{* *}$ & 16 & $56 \%(9 / 16)$ \\
\hline+ & $+\mathrm{m}_{4} \mathrm{R}$ antagonist & $0 \times 0-M$ & $-24.7 \pm 11.1^{* *}$ & 16 & $44 \%(7 / 16)$ \\
\hline+ & $+m_{1} R / m_{3} R$ antagonist & $0 \times 0-M$ & $-0.67 \pm 0.20^{* *}$ & 16 & $0 \%(0 / 16)$ \\
\hline
\end{tabular}

Compiled data show PC12 cells grown in the absence or presence of NGF. Experimental conditions include transfection of $\mathrm{CDNA}$ for $\mathrm{m}_{2}$ muscarinic receptor $\left(+m_{2} R\right)$, $C D N A$ for $G A B A_{B} R 1$ and R2 subunits, or exposure to the indicated muscarinic receptor antagonists. Endogenous Kir3 currents were tested for activation with the muscarinic agonist $0 \times 0-M(100 \mathrm{nM})$, the $\mathrm{GABA}_{B}$ receptor agonist baclofen $(100 \mu \mathrm{M})$, or the $\mathrm{G}$-protein-independent activator ethanol (200 $\mathrm{mM})$. Current densities are mean \pm SEM for the total $n$ at $-120 \mathrm{mV}$. Responses less than $-1 \mathrm{pA} / \mathrm{pF}$ were not considered significant. *indicates statistical significance versus with NGF-no treatment group $(p<0.05)$; ${ }^{* *}$ indicates statistical significance versus with NGF- $\mathrm{m}_{1} / \mathrm{m}_{3}$ treatment group $(p<0.05)$ (for details, see Results). contrast to NGF-differentiated PC12 cells (no atropine), there now appears to be plasma membrane staining for $\mathrm{m}_{2}$ or $\mathrm{m}_{4}$ muscarinic receptors in PC12 cells pretreated with atropine (Fig. 4B,C), compared with primarily perinuclear staining in controls (Fig. $2 I, K$ ). Together, these experiments show that inhibiting activation of endogenous muscarinic receptors with the nonselective antagonist atropine rescues both $\mathrm{m}_{2}$ and $\mathrm{m}_{4}$ muscarinic receptor as well as HA-Kir3.2c channel plasma membrane expression.

We next examined whether NGFdifferentiated PC12 cells pretreated with atropine would now exhibit an endogenous muscarinic receptor-activated Kir3 current. Indeed, in NGF-differentiated PC12 cells treated with atropine for $2 \mathrm{~h}$, Oxo-M (100 nM) elicited large inwardly rectifying Kir3 currents (Table 1, Fig. $4 D, E)$. Note the rapid activation kinetics in the Oxo-M-induced current (Fig. 4E), suggesting that most of the functional Kir3 channels lack the Kir3.1 subunit and therefore likely exist as Kir3.2c homotetramers (Slesinger et al., 1996). To confirm that the muscarinic-activated current was mediated by Kir3 channels, we investigated the effect of the $\mathrm{D}_{1}$ dopamine receptor antagonist $\mathrm{SCH}-23390[(R)-$ (+)-7-chloro-8-hydroxy-3-methyl-1phenyl-2,3,4,5-tetrahydro- $1 H$-3-benzazepine hydrochloride], which selectively blocks endogenous Kir3 channel conductance but does not inhibit members of the closely related Kir2 family of inwardly rectifying potassium channels (Kuzhikandathil and Oxford, 2002). SCH-23390 (30 $\mu \mathrm{M})$ completely inhibited the Oxo-Mactivated current (Fig. $4 F$ ), further substantiating muscarinic activation of endogenous Kir3 channels in the PC12 cells. Furthermore, ethanol-activated Kir3.2 currents $(-38.8 \pm 6.7 \mathrm{pA} / \mathrm{pF} ; n=21)$ were now evident from NGF-differentiated PC12 cells treated with atropine. Muscarinic-activated and ethanol-activated Kir3 currents were observed in $\sim 50-60 \%$ of the cells (Table 1, Fig. 5). This finding adds support to the possibility of Kir3 channel and muscarinic receptor coregulation. The lack of response may reflect different degrees of NGF-mediated differentiation and/or $\mathrm{m}_{2} / \mathrm{m}_{4}$ muscarinic receptor/Kir3 channel trafficking. In contrast to the NGF-differentiated PC12 cells, however, muscarinic-activated Kir3 currents were not observed in undifferentiated $\mathrm{PC} 12$ cells pretreated for $2 \mathrm{~h}$ in atropine (Table 1). Thus, expression of the Kir3 channel-PTX-sensitive complex oc- 
curs only in NGF-differentiated cells, after upregulation of the channels and receptors.

To provide additional evidence that $\mathrm{m}_{2}$ muscarinic receptors were expressed at low levels before atropine treatment, we investigated the surface expression of the $\mathrm{m}_{2}$ receptor using TIRF microscopy. TIRF allows visualization of proteins in the plasma membrane and submembrane regions of a depth of $\sim 100 \mathrm{~nm}$ only (Axelrod et al., 1983). In NGF-differentiated PC12 cells transfected with $\mathrm{m}_{2}$ receptor fused to CFP, $\mathrm{m}_{2}-\mathrm{CFP}$ could be visualized by epifluorescence but not by TIRF (Fig. $6 A$ ). Treating the cells for $2 \mathrm{~h}$ in atropine, however, led to dramatically increased levels of fluorescence using TIRF microscopy (Fig. 6A). Quantitation of the levels of fluorescence on the plasma membrane revealed a significant increase in surface expression of $\mathrm{m}_{2}$ muscarinic receptors after atropine treatment (Fig. 6C). Interestingly, coexpression of both Kir3.2c channel and $\mathrm{m}_{2}-$ CFP receptor did not lead to surface expression of $\mathrm{m}_{2}$ muscarinic receptors in the absence of atropine (Fig. $6 C)$.

One possible mechanism to explain the lack of both the $\mathrm{m}_{2}$ muscarinic receptors and Kir3.2c channels is that chronic stimulation of muscarinic receptors causes endocytosis of the $\mathrm{m}_{2}$ receptor/channel complex. To explore this further, we examined the effect of pharmacologically disrupting endocytosis with wortmannin, an inhibitor of phosphatidylinositol 3/phosphatidylinositol 4 kinases and endocytosis. NGF-differentiated PC12 cells were transfected with cDNA for the $\mathrm{m}_{2}-$ CFP receptor and exposed to wortmannin $(10 \mu \mathrm{M})$ for $2 \mathrm{~h}$ at $37^{\circ} \mathrm{C}$. Using TIRF microscopy, the levels of $\mathrm{m}_{2}-\mathrm{CFP}$ receptor expressed on the plasma membrane were significantly increased above control cells and similar to atropine-treated cells (Fig. $6 B, C)$. Although GPCRs are well known for their ability to undergo endocytosis during chronic stimulation, the concomitant loss of the effector, Kir3 channels, on the plasma membrane surface was unexpected (see Discussion).

\section{Both natively expressed $\mathrm{m}_{2}$ and $\mathrm{m}_{4}$ muscarinic receptors complex with Kir3.2 channels}

To further characterize the rescue of the muscarinic receptor/ Kir3.2c complex, we examined the effect of specific muscarinic receptor antagonists. Seven day NGF-differentiated PC12 cells were pretreated with either $100 \mathrm{nM}$ of the $\mathrm{m}_{2}$ muscarinic receptor antagonist AF-DX116 (Waelbroeck et al., 1990) or $200 \mathrm{nM}$ of the $\mathrm{m}_{4}$ muscarinic receptor antagonist tropicamide (Lazareno et al., 1993). Based on previous studies, these concentrations selectively inhibited each muscarinic receptor subtype studied (Waelbroeck et al., 1990; Lazareno et al., 1993; Shi et al., 1999). However, we
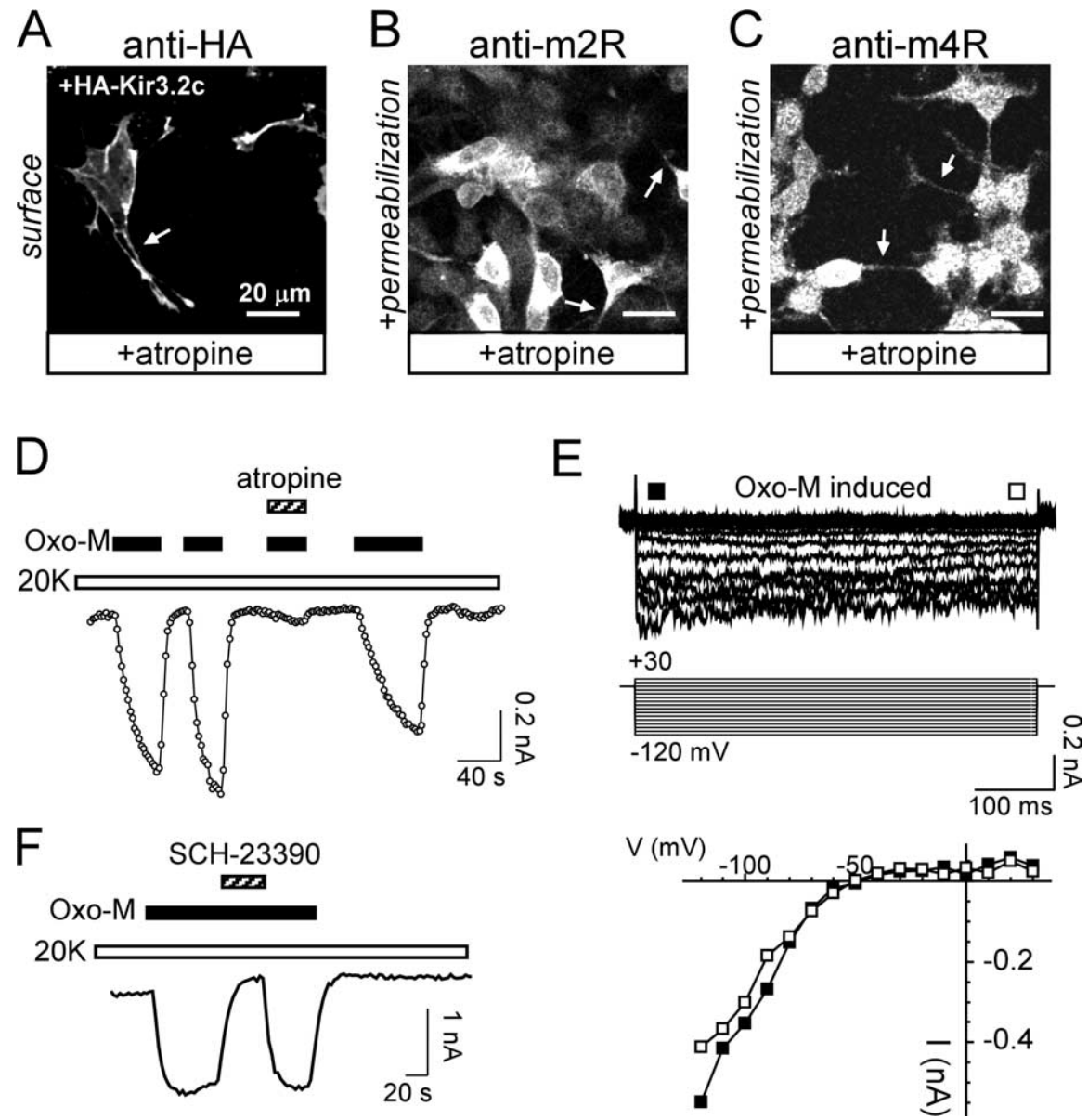

Figure 4. Muscarinic receptor antagonists rescue Kir3 signaling in NGF-differentiated PC12 cells. $\boldsymbol{A}$, NGF-differentiated PC12 cells transfected with $\mathrm{HA}-\mathrm{Kir} 3.2 \mathrm{c}$ were treated with atropine (100 $\mu \mathrm{M}$ for $2 \mathrm{~h}$ ) and immunostained with anti-HA antibodies without permeabilization. Note prominent surface expression of HA-Kir3.2C (arrows). B, NGF-differentiated PC12 cells were carinic receptors are expressed on prosses in tropinecurrent recording from NGF-differentiated PC12 cell treated with atropine. Atropine was removed from treated cells just before voltage steps from -120 to $+30 \mathrm{mV}$ (holding potential was $0 \mathrm{mV}$ ). Trace shows the difference between with $0 \times 0-\mathrm{M}(100 \mathrm{~nm})$ and basal (20K). The current-voltage plot shows the current level at the beginning $(\square)$ and end $(\square)$ of the voltage step. Note the strong inward rectification, presence of fast activation kinetics, and zero-current potential near $E_{\mathrm{K}}(-50 \mathrm{mV})$. $\boldsymbol{F}$, Muscarinicactivated currents are mediated by endogenous Kir3 channels. Representative whole-cell recording from NGF-differentiated PC12 cells treated with atropine. Plot shows current at $-120 \mathrm{mV}$ with 0xo (100 nM)-activated currents in the absence or presence of SCH-23390 (30 $\mu \mathrm{M})$, a selective inhibitor of Kir3 channels (Kuzhikandathil and Oxford, 2002).

cannot completely rule out the possibility that these antagonists may exhibit some cross-reactivity (Dei et al., 1996).

Like atropine, a $2 \mathrm{~h}$ pretreatment with either the $\mathrm{m}_{2}$ muscarinic receptor antagonist AF-DX116 or the $\mathrm{m}_{4}$ muscarinic receptor antagonist tropicamide rescued $\mathrm{m}_{2}$ and $\mathrm{m}_{4}$ muscarinic receptor plasma membrane expression, respectively (Fig. 7A,B). Similarly, NGF-differentiated PC12 cells transfected with HAKir3.2c and pretreated with AF-DX116 (100 nM) or tropicamide $(200 \mathrm{nM})$ for $2 \mathrm{~h}$ rescued HA-Kir3.2c plasma membrane expression (Fig. 7C-E).

We then used whole-cell patch clamp to measure the frequency and amplitude of Oxo-M-activated currents in cells pretreated $(2 \mathrm{~h})$ with each selective muscarinic receptor antagonist. The $\mathrm{m}_{2}$ muscarinic receptor antagonist AF-DX116 (100 nM) and the $\mathrm{m}_{4}$ muscarinic receptor antagonist tropicamide $(200 \mathrm{nM})$ 


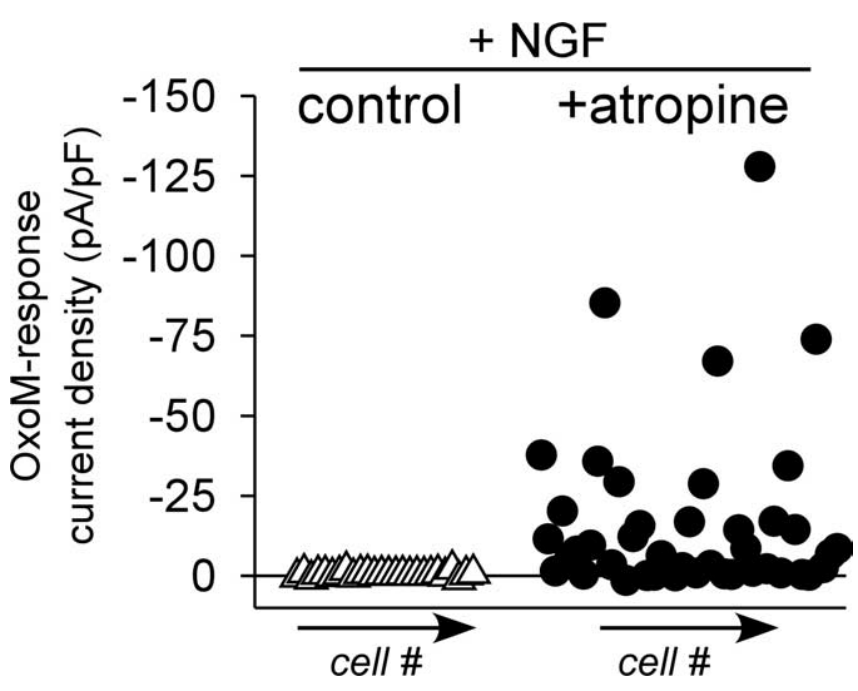

Figure 5. Summary of oxotremorine-M responses in NGF-differentiated PC12 cells. Cumulative plot shows current density for $0 \times 0-M$-activated currents in control and atropine-treated NGF-differentiated PC12 cells for each cell. Functional coupling was observed in $~ 50 \%$ of NGF-differentiated PC12 cells ( $n=43)$. Control cells did not demonstrate a detectable muscarinic receptor-mediated Kir3 current $(n=26)$. No detectable 0xo-M-activated (100 nm) Kir3 currents were observed in control $(n=19)$ and atropine-treated $(n=19)$ undifferentiated PC12 cells (Table 1). Thus, surface expression of the GPCR/Kir3 channel complex occurs only in atropine-treated NGF-differentiated cells.

both rescued endogenous muscarinic receptor-activated Kir3 currents (Table 1, Fig. 7F). Like atropine, Oxo-M activation of Kir3 channels was evident in $\sim 50 \%$ of the cells analyzed (Fig. $7 F)$, suggesting a similar GPCR-mediated plasma membrane surface regulatory mechanism. In contrast, $2 \mathrm{~h}$ pretreatment with antagonists for both $\mathrm{m}_{1} / \mathrm{m}_{3}$ muscarinic receptors (Shi et al., 1999) did not rescue Oxo-M-activated Kir3 currents (Table 1, Fig. $7 F$ ). Together, these findings implicate the existence of an endogenous Kir3.2c channel-PTX-sensitive muscarinic receptor signaling complex, whose expression levels on the surface are regulated by the extent of cholinergic activity.

Having ascertained that both $\mathrm{m}_{2}$ and $\mathrm{m}_{4}$ muscarinic receptor antagonists rescue HA-Kir3.2c channel plasma membrane expression and importantly endogenous Kir3 channel activation, we next investigated which PTX-sensitive muscarinic receptor couples to the natively expressed Kir3 channels. Whole-cell patch-clamp studies on atropine rescued $7 \mathrm{~d}$ NGF-differentiated PC12 cells demonstrated that Oxo-M-activated currents were inhibited by $\sim 40 \%$ by the selective $\mathrm{m}_{2}$ muscarinic receptor antagonist AF-DX116 (100 nM); total inhibition was evident when the selective $\mathrm{m}_{4}$ muscarinic receptor antagonist tropicamide (200 $\mathrm{nM}$ ) was applied in combination (Fig. $8 A, B$ ). These data suggest that both $\mathrm{m}_{2}$ and $\mathrm{m}_{4}$ muscarinic receptors couple with Kir3.2c channels in 7 d NGF-differentiated PC12 cells.

\section{Discussion}

We used NGF-differentiated PC12 cells to study the regulation of natively expressed Kir3 channels and muscarinic GPCRs. Two significant new insights into the regulation of Kir3 channels were discovered in these model neurons. First, NGF treatment increases mRNA and protein levels for a subset of Kir3 channels, the splice variant Kir3.2c, as well as the requisite proteins for forming a Kir3 signaling complex $\left(\mathrm{G} \alpha_{\mathrm{o}}\right.$ and $\mathrm{m}_{2} / \mathrm{m}_{4}$ muscarinic receptors). Second, stimulation of endogenous PTX-sensitive $\mathrm{m}_{2} / \mathrm{m}_{4}$ muscarinic receptors appears to self-regulate the surface expression and functional coupling of both the muscarinic receptors and Kir3 channels.

NGF-dependent upregulation of PTX-sensitive G $\alpha_{\mathrm{o}}$ Gproteins, muscarinic receptors, and Kir3 channels

To date, most studies investigating ion channel regulation have relied on heterologous expression systems (i.e., HEK-293 cells and Xenopus oocytes), in which proteins are ectopically expressed at high levels. The regulation of neuronal Kir3 channels is not well understood. Studies in rat brain demonstrated that chronic electroconvulsive shock increases Kir3.2a expression (Pei et al., 1999), and the corticosteroid dexamethasone increases Kir3.1 and Kir3.3 expression in the rat semicircular canal (Pondugula et al., 2006). Here, we demonstrate that muscarinic receptors, $\mathrm{G} \alpha_{\mathrm{o}}$ G-proteins, and Kir3.2c channels are upregulated in NGFdifferentiated PC12 cells. NGF-differentiated PC12 cells are a well established model for studying the regulation of native gene expression (Vaudry et al., 2002; Katoh and Negishi, 2003; An and Almers, 2004; Darios and Davletov, 2006). Elucidating the mechanism of transcriptional control of proteins in the Kir3 signaling complex may be now more feasible with the PC12 cell system.

The selective increase of the $\mathrm{m}_{2} \mathrm{R} / \mathrm{Kir} 3.2 \mathrm{c}$ signaling proteins suggests that receptor activation of Kir3.2c channels may serve an important function for mature neurons. Many mature neurons express Kir3.2c along with other Kir3 subunits. For example, RT-PCR indicates that Kir3.2c is coexpressed with Kir3.1/ Kir3.2a/Kir3.3 subunits in hippocampus (Leaney, 2003). In dopamine neurons, only Kir3.2a and Kir3.2c are expressed in substantia nigra (Inanobe et al., 1999b) while Kir3.2c is coexpressed along with Kir3.3 in ventral tegmental area (Cruz et al., 2004). The selective increase in Kir3.2c is intriguing. Kir3.2c contains a C-terminal PDZ [postsynaptic density-95 (PSD-95)/Discs large/ zona occludens-1]-binding motif, which interacts with the PSD-95 family of membrane-associated guanylate kinases (MAGUKs) proteins (Inanobe et al., 1999b) and sorting nexins (Lunn et al., 2006). The MAGUK family of proteins act as molecular scaffolds that regulate the assembly of multiprotein signaling complexes in the postsynaptic density of excitatory synapses (Kim and Sheng, 2004). Synapse-associated protein-97, a PDZcontaining protein, is endogenously expressed in PC12 cells ( $\mathrm{Wu}$ et al., 2002) and could be involved in stabilizing the postsynaptic expression of Kir3 channels. The selective upregulation of Kir3.2c could be required for appropriate subcellular targeting of Kir3 channels in PC12 cells.

The coincident increase in protein expression of Kir3.2c, G $\alpha_{\mathrm{o}}$, and the muscarinic receptor in NGF-differentiated PC12 cells raises the possibility that expression and functional coupling may require the PTX-sensitive $\mathrm{G} \alpha_{\mathrm{o}}$ subunit Consistent with this idea, we previously demonstrated that $\mathrm{G} \alpha_{\mathrm{o}}$ interacts directly with Kir3 channels and that mutating the $\mathrm{G} \alpha_{\mathrm{o}}$ binding site interferes with Kir3 trafficking to the plasma membrane (Clancy et al., 2005), suggesting the formation of a PTX-sensitive Kir3 channel membrane signaling complex. Furthermore, other studies have demonstrated association between Kir3 channels and different types of GPCRs (Lavine et al., 2002; David et al., 2006; Fowler et al., 2007). However, Kir3 channels can also couple with other $\mathrm{G} \alpha$ G-proteins, which are expressed in PC12 cells (Fig. 1) (Asano et al., 1989; Leyte et al., 1992). Although tempting to speculate, future studies are required to further examine the role of the NGF-mediated upregulation of $\mathrm{G} \alpha_{\mathrm{o}}$ in formation of a Kir3 signaling complex. 
Implications of sequestered GPCR/Kir3 channel signaling complexes

The absence of muscarinic-activated Kir3 currents in NGF-differentiated PC12 cells was unexpected. Treatment with atropine, however, led to robust expression of muscarinic receptor and GPCR independent ethanol activated Kir3 currents. Ectopic expression of either Kir3.2c or $\mathrm{m}_{2}$ muscarinic receptor failed to recover muscarinic-activated Kir3 currents. Thus, ectopically and endogenously expressed channels and receptors in NGFdifferentiated PC12 cells were subjected to the same regulatory mechanism. Immunostaining of the NGF-differentiated PC12 cells transfected with HA-tagged Kir3.2c revealed undetectable levels of Kir3.2c channels on the membrane surface, indicating that the lack of Kir3 currents was attributable to a defect in trafficking and not G-protein gating.

An explanation for the loss of $\mathrm{m}_{2}$ receptor/Kir3 complexes may be that muscarinic receptors and Kir3 channels are sequestered in cytoplasmic compartments. In a mouse mutant containing reduced acetylcholinesterase activity, which increased levels of ambient acetylcholine, muscarinic receptors were expressed in the cytoplasm instead of on the plasma membrane (Bernard et al., 2003). NGFdifferentiated PC12 cells synthesize and release acetylcholine (Greene and Rein, 1977), which could lead to elevated levels of acetylcholine. In response to sustained agonist stimulation, $\mathrm{m}_{2}$ and $\mathrm{m}_{4}$ muscarinic receptors undergo desensitization, which involves dynamin-dependent pathways and either clathrin-independent or clathrin-dependent processes, respectively (Volpicelli et al., 2001; Delaney et al., 2002). Although the two pathways are separate initially, they likely merge in sorting endosomes (Delaney et al., 2002). With chronic stimulation, muscarinic receptors accumulate within the endoplasmic reticulum and Golgi complex and are almost completely depleted on the cell membrane (Liste et al., 2002; Bernard et al., 2003). We propose that NGF-differentiated PC12 cells are persistently stimulated by endogenously released acetylcholine. Accordingly, treatment with the nonselective muscarinic-receptor antagonist atropine, as well as the $\mathrm{m}_{2}$ or $\mathrm{m}_{4}$ receptor antagonists, revealed cell membrane expression of the $\mathrm{m}_{2} / \mathrm{m}_{4}$ muscarinic receptors and Kir3 channels. Furthermore, experiments with wortmannin, an inhibitor of endocytosis, are consistent with this finding.

Approximately $50 \%$ of the NGF-differentiated cells responded to atropine treatment. Similarly, $\sim 40 \%$ of cell surface muscarinic receptor expression is recovered $2 \mathrm{~h}$ after removal of muscarinic agonist (Delaney et al., 2002). Thus, NGFdifferentiated PC12 cells likely represent a heterogeneous population of neurons. Interestingly, Goin and Nathanson (2006) have demonstrated in JEG-3 cells the existence of heterooligomeric $m_{2}-m_{4}$ complexes, containing the $m_{3}$ and/or the $m_{1}$
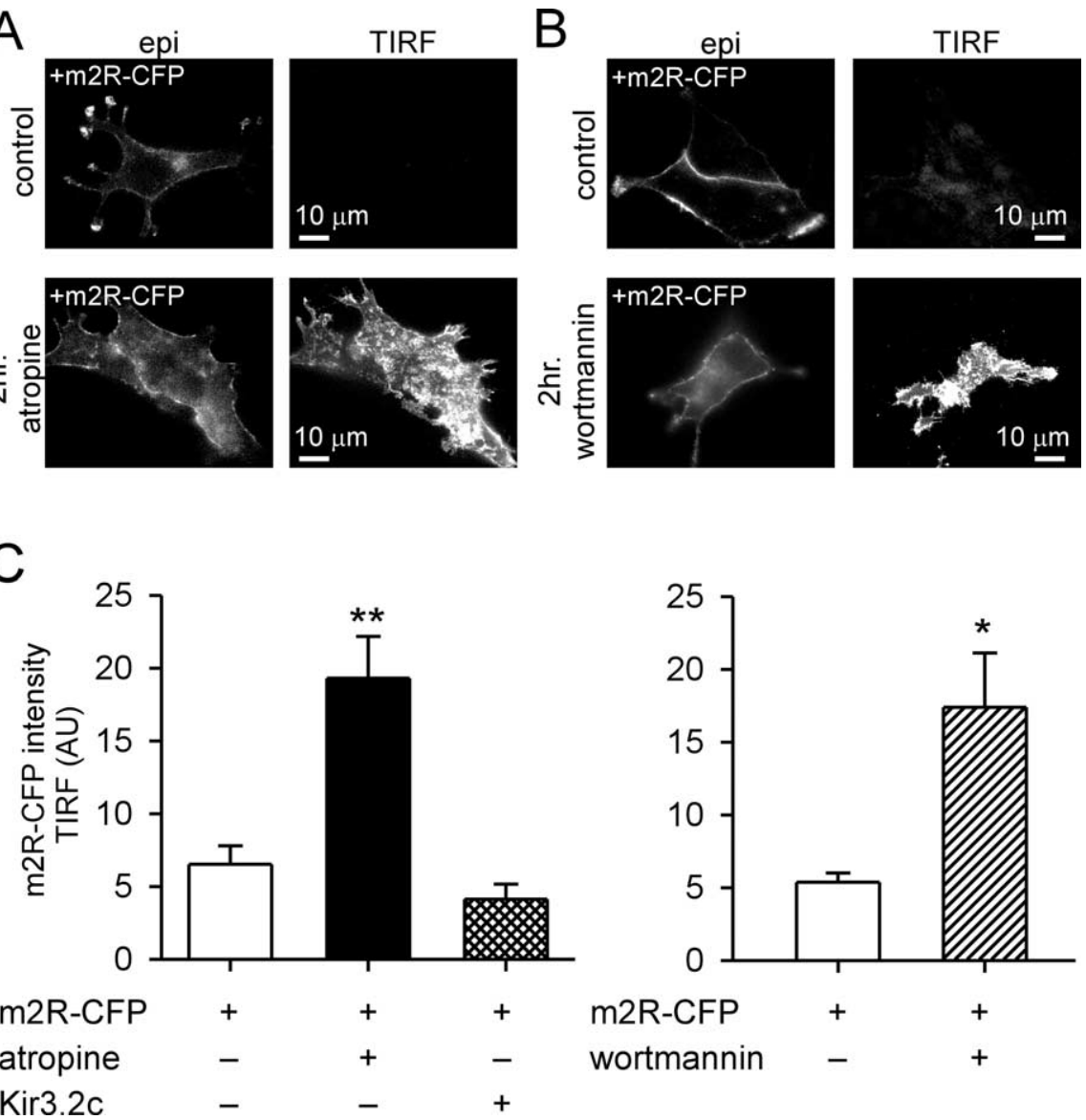

$\begin{array}{lll}\text { m2R-CFP } & + & + \\ \text { wortmannin } & - & +\end{array}$

Figure 6. Muscarinic receptor antagonist atropine or endocytosis inhibitor wortmannin promotes surface expression of $m_{2}$ $(10 \mu \mathrm{m})$ for $2 \mathrm{~h}$ at $37^{\circ} \mathrm{C}$. C, Mean fluorescence measured under TIRF is shown for two different experiments: control $(n=23)$, plus (20) and plus Kir3.2c $(n=10)$, and control $(n=17)$ or plus wortmannin $(n=14)$. Both atropine and wortmannin one-way ANOVA with Dunnett's post hoc). Fluorescence measured for $m 2 \mathrm{R}$-CFP alone $[\sim 5$ arbitrary units (AU)] could be from cytoplasmic or membrane receptors. In addition to TIRF microscopy, mean (FP fluorescence was measured using epifluorescence illumination [atropine experiment: $8.6 \pm 1.9 \mathrm{AU}$ for control, $15.2 \pm 2.3 \mathrm{AU}$ for plus atropine, and $7.3 \pm 1.9 \mathrm{AU}$ for plus Kir3.2C cDNA; wortmannin experiment: $4.2 \pm 0.6 \mathrm{AU}$ for control and $12.8 \pm 3.2 \mathrm{AU}$ for plus wortmannin].

muscarinic receptors. However, the inability of the $\mathrm{m}_{1}$ and $\mathrm{m}_{3}$ receptor-specific antagonists to rescue muscarinic receptoractivated Kir3.2 currents suggests that this assembly of receptors is unlikely in NGF-differentiated PC12 cells.

Although expression of $\mathrm{m}_{2} / \mathrm{m}_{4}$ receptors and Kir3.2 channels in NGF-differentiated PC12 cells is predominantly intracellular, we cannot rule out the possibility that plasma membrane expression of the muscarinic receptors and/or Kir3.2c channel was too low to be detected by immunostaining or electrophysiology. In fact, a small and transient reserve of PTX-sensitive $\mathrm{m}_{2} / \mathrm{m}_{4}$ muscarinic receptors on the cell surface may be needed for the muscarinic receptor antagonists to inhibit activation from endogenously released acetylcholine. Alternatively, the muscarinic receptor antagonists may permeate the cell membrane and act as a "pharmacochaparone" (Wuller et al., 2004) to increase GPCRKir3.2 trafficking from the cytoplasm the cell surface. After the reduction in cholinergic activation, fewer muscarinic receptor/ Kir3 channel complexes internalize and/or other receptor/Kir3 channel complexes are retargeted from endosomal compart- 

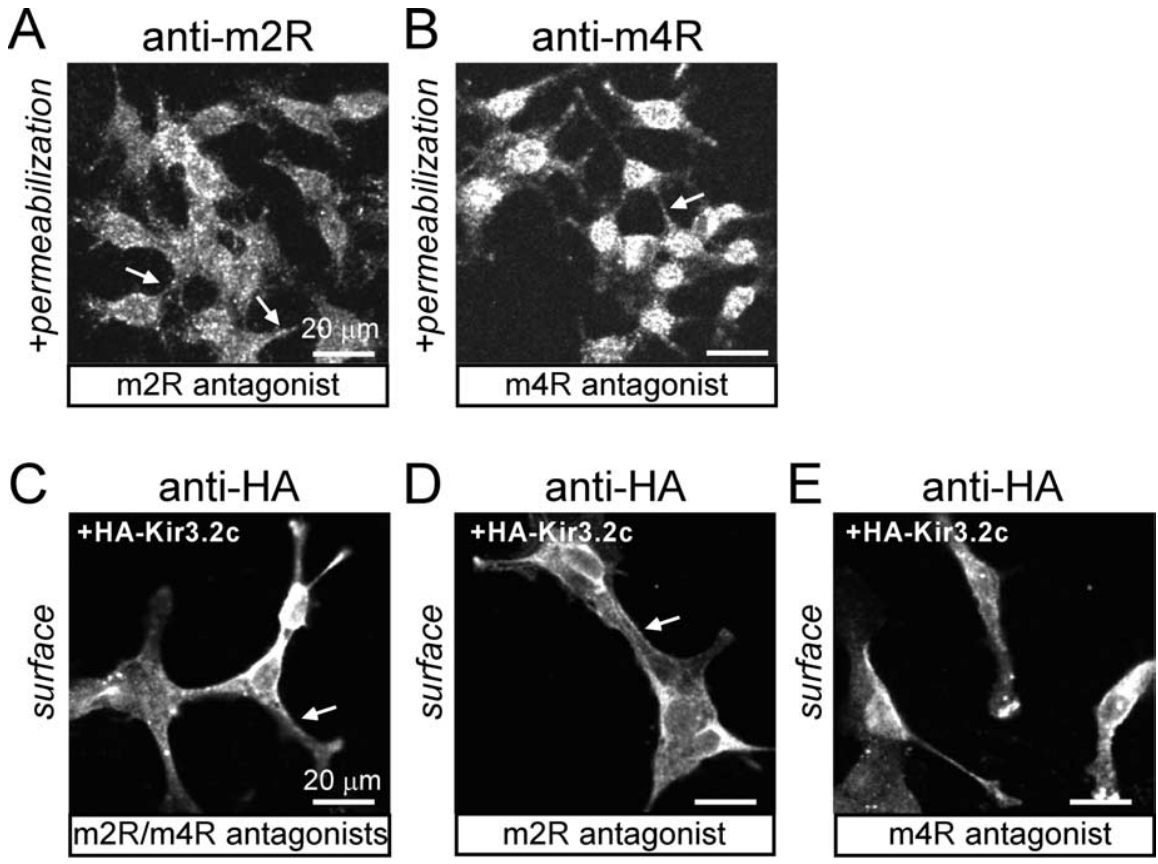

$\mathrm{F}$

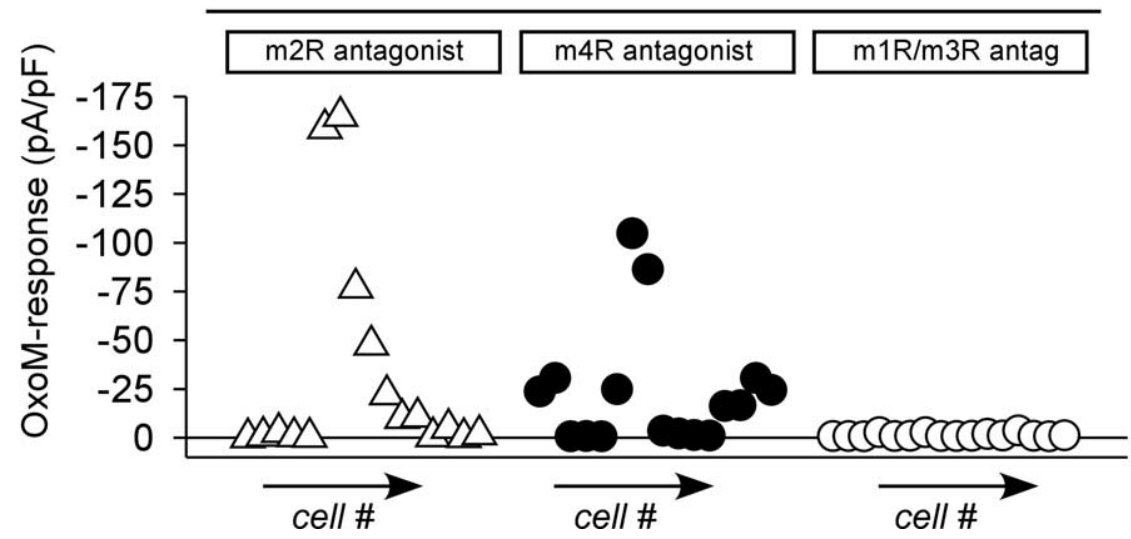

Figure 7. Selective inhibition of $\mathrm{m}_{2}$ or $\mathrm{m}_{4}$ muscarinic receptors rescues Kir3 signaling in NGF-differentiated PC12 cells. Immunostaining studies revealed that $2 \mathrm{~h}$ pretreatment with either the $\mathrm{m}_{2}$ muscarinic-receptor antagonist (100 nM) AF-DX116 (A) or the $\mathrm{m}_{4}$ muscarinic-receptor antagonist tropicamide $(200 \mathrm{~nm})(\boldsymbol{B})$ rescued $\mathrm{m}_{2}$ and $\mathrm{m}_{4}$ muscarinic receptor plasma membrane expression, respectively. $\boldsymbol{C}-\boldsymbol{E}$, NGF-differentiated $\mathrm{PC} 12$ cells transfected with $\mathrm{HA}-$ Kir3.2c and incubated for $2 \mathrm{~h}$ in the $\mathrm{m}_{2}$ muscarinic antagonist (AF-DX116) or the $\mathrm{m}_{4}$ muscarinic antagonist (tropicamide). Each muscarinic receptor antagonist pretreatment resulted in surface expression of $\mathrm{HA}-\mathrm{Kir} 3.2 \mathrm{C}$. $\boldsymbol{F}$, Cumulative plot shows current density for $0 \mathrm{x}_{0}$-M-activated currents in $\mathrm{m}_{2}$-antagonisttreated, $\mathrm{m}_{4}$ antagonist-treated, or $\mathrm{m}_{1} / \mathrm{m}_{3}$ (pirenzipine, 4-DAMP)-treated NGF-differentiated PC12 cells. Both the $\mathrm{m}_{2}$ muscarinic receptor antagonist and the $m_{4}$ muscarinic receptor antagonist treatments led to significant muscarinic receptor-activated Kir3 currents compared with $\mathrm{m}_{1} / \mathrm{m}_{3}$ antagonists treatment ( $p<0.05$, one-way ANOVA on ranks followed by Tukey's post hoc test). Conversely, $m_{1} / m_{3}$ muscarinic receptor antagonist did not rescue muscarinic-activated Kir3 currents. Current densities for $m_{2}$ antagonist treatment were $-31.4 \pm 13.8 \mathrm{pA} / \mathrm{pF}(n=16)$, for $\mathrm{m}_{4}$ antagonist treatment $-22.3 \pm 7.7 \mathrm{pA} / \mathrm{pF}(n=16)$, and for $\mathrm{m}_{1} / \mathrm{m}_{3}$ antagonists treatment $-0.69 \pm 0.24 \mathrm{pA} / \mathrm{pF}(n=16)$.

ments to the cell membrane (supplemental Fig. S1, available at www.jneurosci.org as supplemental material).

Use of selective muscarinic receptor antagonists demonstrated that the same $\mathrm{m}_{2} / \mathrm{m}_{4}$ muscarinic receptor family that activates Kir3 channels also regulates Kir3 channel expression on the plasma membrane. These findings suggest that Kir3 channel cell membrane expression is regulated by both G-proteins and endocytosis via activation of the GPCR. Trafficking of the Kir3 channel with the muscarinic receptor was unexpected; for example, carbachol stimulation of muscarinic receptors in atrial myocytes decreased levels of surface receptors but not Kir3.1/3.4 channels (Shui et al., 2001). A similar mechanism of dual regulation of $\mathrm{N}$-type voltage-gated $\mathrm{Ca}^{2+}$ channels and opioid receptor-like receptors 1 was recently reported; agonist stimulation triggered the vesicular internalization of the both the receptor and $\mathrm{Ca}^{2+}$ channel in rat dorsal root ganglion cells, providing a key mechanism for regulating $\mathrm{Ca}^{2+}$ channel activity (Altier et al., 2006). This novel form of dual regulation raises interesting questions for muscarinic receptors and Kir3 channels. First, is channel activity required for dual regulation? This is unlikely, because PTX treatment only delays but does not prevent receptor internalization (Roseberry et al., 2001). Second, does muscarinic receptor-mediated endocytosis affect other effectors? The agonistinduced internalization of the $\mathrm{m}_{2} / \mathrm{m}_{4}$ receptors could lead to a decrease in the potency of a muscarinic-dependent inhibition of adenylyl cyclase (Rousell et al., 1997; Goin and Nathanson, 2006). Interestingly, previous studies in PC12 cells have demonstrated enhanced cAMP accumulation by muscarinic agonist stimulation (Pinkas-Kramarski et al., 1992).

\section{Physiological significance of coregulated muscarinic receptors and Kir3 channels}

Our study illustrates a novel dynamic and adaptive mechanism for regulating neuronal Kir3 signaling. The PTX-sensitive muscarinic receptor-mediated internalization of Kir3.2c could represent an important pathway for self-regulating physiological responses according to the neurochemical environment. NGF enhances the release of acetylcholine from rat hippocampal synaptic terminals, whereas cholinergic neuronal activity regulates the level of NGF release (Knipper et al., 1994). This reciprocal regulation of acetylcholine and NGF in the brain may allow the two ligands to cooperatively control physiological actions such as neuronal survival. Cholinergic neurons innervate cerebral cortex during the most dynamic period of neuronal differentiation and synapse formation (Hohmann and Berger-Sweeney, 1998), and acetylcholine gradients can direct the growth of neuronal growth cones via changes in intracellular $\mathrm{Ca}^{2+}$ (Zheng et al., 1994). Removal of the GPCR/Kir3.2c channel complex from the membrane surface would prevent a long-term reduction in excitability from occurring, which could interfere with synaptogenesis or neurite growth (Samsonovich and Ascoli, 2006). Finally, the situation of persistently stimulated muscarinic receptors observed with PC12 cells may also exist in the brain. In addition to synaptically released acetylcholine, diffuse transmission of acetylcholine occurs, which leads to elevated levels of extracellular acetylcholine (Descarries et al., 1997). This pathway 


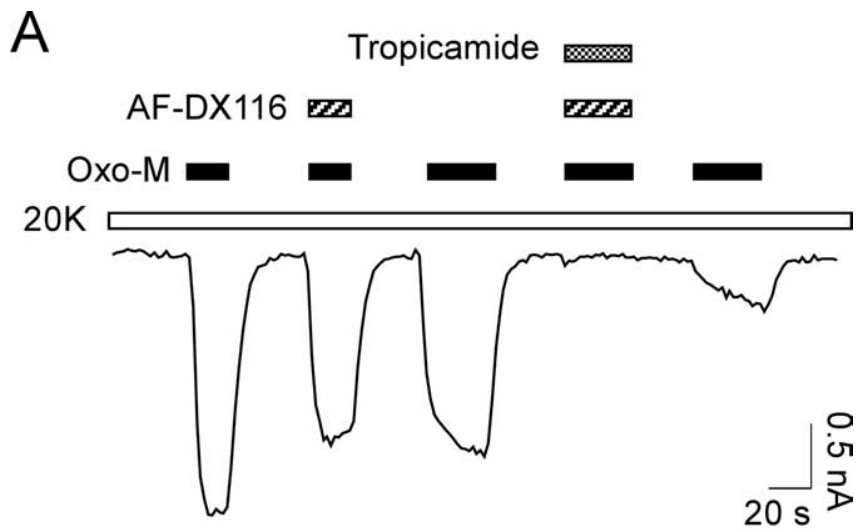

B

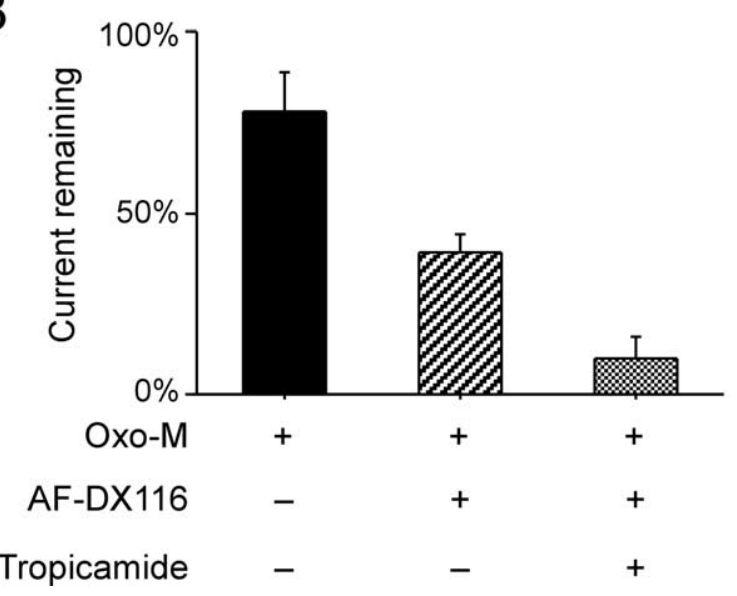

Figure 8. Both $\mathrm{m}_{2}$ and $\mathrm{m}_{4}$ muscarinic receptors couple with endogenous Kir3 channels. $A$, Whole-cell current recording from NGF-differentiated $\mathrm{PC} 12$ cells pretreated with atropine (100 $\mu \mathrm{m}$ for $2 \mathrm{~h}$ ). $0 \times 0-\mathrm{M}(100 \mathrm{~nm})$ activates endogenous Kir3 current and is partially inhibited by $(\sim 40 \%)$ the selective $m_{2}$ muscarinic receptor antagonist AF-DX116 (100 nM) and completely inhibited with coapplication of both $\mathrm{m}_{2}$ (AF-DX116, $100 \mathrm{~nm}$ ) and $\mathrm{m}_{4}$ (tropicamide, $200 \mathrm{~nm}$ ) muscarinic receptor antagonists. $\boldsymbol{B}$, Bar graph shows the percentage of $0 \times 0-M(100 \mathrm{nM})$ mediated response current remaining after either two consecutive $0 \times 0-M$ pulses (which shows some desensitization), a selective $m_{2}$ muscarinic receptor antagonist AF-DX116 (100 nM), or coapplication of the both $\mathrm{m}_{2}$ and $\mathrm{m}_{4}$ muscarinic receptor antagonists $(n=8)$.

for controlling Kir3 signaling could be one way to limit the potential harmful effects of excessive Kir3 channel activity in the brain.

\section{References}

Altier C, Khosravani H, Evans RM, Hameed S, Peloquin JB, Vartian BA, Chen L, Beedle AM, Ferguson SSG, Mezghrani A, Dubel SJ, Bourinet E, McRory JE, Zamponi GW (2006) ORL1 receptor-mediated internalization of N-type calcium channels. Nat Neurosci 9:31-40.

An SJ, Almers W (2004) Tracking SNARE complex formation in live endocrine cells. Science 306:1042-1046.

Andreopoulos S, Li PP, Warsh JJ (1995) Developmental expression of G $\alpha$ o and $\mathrm{G} \alpha$ s isoforms in PC12 cells: relationship to neurite outgrowth. Dev Brain Res 88:30-36.

Asano T, Morishita R, Sano M, Kato K (1989) The GTP-binding proteins, Go and Gi2, of neural cloned cells and their changes during differentiation. J Neurochem 53:1195-1198.

Axelrod D, Thompson NL, Burghardt TP (1983) Total internal inflection fluorescent microscopy. J Microsc 129:19-28.

Bernard V, Brana C, Liste I, Lockridge O, Bloch B (2003) Dramatic depletion of cell surface $\mathrm{m} 2$ muscarinic receptor due to limited delivery from intracytoplasmic stores in neurons of acetylcholinesterase-deficient mice. Mol Cell Neurosci 23:121-133.

Chuang H-H, Yu M, Jan YN, Jan LY (1998) Evidence that the nucleotide exchange and hydrolysis cycle of $\mathrm{G}$ proteins causes acute desensitization of G-protein gated inward rectifier $\mathrm{K}^{+}$channels. Proc Natl Acad Sci USA 95:11727-11732.

Chung CY, Seo H, Sonntag KC, Brooks A, Lin L, Isacson O (2005) Cell type-specific gene expression of midbrain dopaminergic neurons reveals molecules involved in their vulnerability and protection. Hum Mol Genet 14:1709-1725.

Clancy S, Fowler C, Finley M, Arrabit C, Suen K-F, Berton F, Kozasa T, Casey P, Slesinger PA (2005) Pertussis-toxin-sensitive G $\alpha$ subunits selectively bind to C-terminal domain of neuronal GIRK channels: evidence for a heterotrimeric G-protein-channel complex. Mol Cell Neurosci 28:375-389.

Cruz HG, Ivanova T, Lunn ML, Stoffel M, Slesinger PA, Lüscher C (2004) Bi-directional effects of $\mathrm{GABA}_{\mathrm{B}}$ receptor agonists on the mesolimbic dopamine system. Nat Neurosci 7:153-159.

Darios F, Davletov B (2006) Omega-3 and omega-6 fatty acids stimulate cell membrane expansion by acting on syntaxin 3 . Nature 440:813-817.

Dascal N (1997) Signalling via the G protein-activated $\mathrm{K}^{+}$channels. Cell Signal 9:551-573.

David M, Richer M, Mamarbachi AM, Villeneuve LR, Dupre DJ, Hebert TE (2006) Interactions between GABA-B1 receptors and Kir 3 inwardly rectifying potassium channels. Cell Signal 18:2172-2181.

Dei S, Bellucci C, Ghelardini C, Romanelli MN, Spampinato S (1996) Synthesis, characterization and pharmacological profile of tropicamide enantiomers. Life Sci 58:2147-2153.

Delaney KA, Murph MM, Brown LM, Radhakrishna H (2002) Transfer of M2 muscarinic acetylcholine receptors to clathrin-derived early endosomes following clathrin-independent endocytosis. J Biol Chem 277:33439-33446.

Descarries L, Gisiger V, Steriade M (1997) Diffuse transmission by acetylcholine in the CNS. Prog Neurobiol 53:603-625.

Dichter MA, Tischler AS, Greene LA (1977) Nerve growth factor-induced increase in electrical excitability and acetylcholine sensitivity of a rat pheochromocytoma cell line. Nature 268:501-504.

Finley M, Arrabit C, Fowler C, Suen KF, Slesinger PA (2004) $\beta \mathrm{L}-\beta \mathrm{M}$ loop in the C-terminal domain of GIRK channels is important for G $\beta \gamma$ activation. J Physiol (Lond) 555:643-657.

Fowler CE, Aryal P, Suen KF, Slesinger PA (2007) Evidence for association of GABAB receptors with Kir3 channels and RGS4 proteins. J Physiol (Lond) 580:51-65.

Goin JC, Nathanson NM (2006) Quantitative analysis of muscarinic acetylcholine receptor homo- and heterodimerization in live cells: regulation of receptor down-regulation by heterodimerization. J Biol Chem 281:5416-5425.

Greene LA, Rein G (1977) Synthesis, storage and release of acetylcholine by a noradrenergic pheochromocytoma cell line. Nature 268:349-351.

Greene LA, Tischler AS (1982) PC12 pheochromocytoma cultures in neurobiological research. Adv Cell Neurobiol 3:373-414.

Hamill OP, Marty A, Neher E, Sakmann B, Sigworth FJ (1981) Improved patch-clamp techniques for high-resolution current recording from cells and cell-free membrane patches. Pflügers Arch 391:85-100.

Hedin KE, Lim NF, Clapham DE (1996) Cloning of a Xenopus laevis inwardly rectifying $\mathrm{K}^{+}$channel subunit that permits GIRK1 expression of $\mathrm{I}_{\text {KACh }}$ currents in oocytes. Neuron 16:423-429.

Hohmann CF, Berger-Sweeney J (1998) Cholinergic regulation of cortical development and plasticity. New twists to an old story. Perspect Dev Neurobiol 5:401-425.

Inanobe A, Horio Y, Fujita A, Tanemoto M, Hibino H, Inageda K, Kurachi Y (1999a) Molecular cloning and characterization of a novel splicing variant of the Kir3.2 subunit predominantly expressed in mouse testis. J Physiol (Lond) 521:19-30.

Inanobe A, Yoshimoto Y, Horio Y, Morishige K-I, Hibino H, Matsumoto S, Tokunaga Y, Maeda T, Hata Y, Takai Y, Kurachi Y (1999b) Characterization of G-protein-gated $\mathrm{K}^{+}$channels composed of Kir3.2 subunits in dopaminergic neurons of the substantia nigra. J Neurosci 19:1006-1017.

Isomoto S, Kondo C, Kurachi Y (1997) Inwardly rectifying potassium channels: their molecular heterogeneity and function. Jpn J Physiol 47:11-39.

Ivanina T, Varon D, Peleg S, Rishal I, Porozov Y, Dessauer CW, KerenRaifman T, Dascal N (2004) G-alpha-il and G-alpha-i3 differentially interact with, and regulate, the $\mathrm{G}$ protein-activated $\mathrm{K}^{+}$channel. J Biol Chem 279:17260-17268.

Jaen C, Doupnik CA (2006) RGS3 and RGS4 differentially associate with G protein-coupled receptor-Kir3 channel signaling complexes revealing 
two modes of RGS modulation: precoupling and collision coupling. J Biol Chem 281:34549-34560.

Jelacic TM, Sims SM, Clapham DE (1999) Functional expression and characterization of G-protein-gated inwardly rectifying $\mathrm{K}^{+}$channels containing GIRK3. J Membr Biol 169:123-129.

Katoh H, Negishi M (2003) RhoG activates Racl by direct interaction with the Dock180-binding protein Elmo. Nature 424:461-464.

Kennedy ME, Nemec J, Clapham DE (1996) Localization and interaction of epitope-tagged GIRK1 and CIR inward rectifier $\mathrm{K}^{+}$channel subunits. Neuropharmacology 35:831-839.

Kim E, Sheng M (2004) PDZ domain proteins of synapses. Nat Rev Neurosci 5:771-781.

Knipper M, da Penha Berzaghi M, Blochl A, Breer H, Thoenen H, Lindholm D (1994) Positive feedback between acetylcholine and the neurotrophins nerve growth factor and brain-derived neurotrophic factor in the rat hippocampus. Eur J Neurosci 6:668-671.

Kobrinsky E, Mirshahi T, Zhang H, Jin T, Logothetis DE (2000) Receptormediated hydrolysis of plasma membrane messenger $\mathrm{PIP}_{2}$ leads to $\mathrm{K}^{+}$current desensitization. Nat Cell Biol 2:507-514.

Kuzhikandathil EV, Oxford GS (2002) Classic D1 dopamine receptor antagonist $\quad R$-(+)-7-chloro-8-hydroxy-3-methyl-1-phenyl-2,3,4,5tetrahydro- $1 \mathrm{H}$-3-benzazepine hydrochloride (SCH23390) directly inhibits $\mathrm{G}$ protein-coupled inwardly rectifying potassium channels. Mol Pharmacol 62:119-126.

Lavine N, Ethier N, Oak JN, Pei L, Liu F, Trieu P, Rebois RV, Bouvier M, Hebert TE, Van Tol HH (2002) G protein-coupled receptors form stable complexes with inwardly rectifying potassium channels and adenylyl cyclase. J Biol Chem 277:46010-46019.

Lazareno S, Farries T, Birdsall NJ (1993) Pharmacological characterization of guanine nucleotide exchange reactions in membranes from $\mathrm{CHO}$ cells stably transfected with human muscarinic receptors m1-m4. Life Sci 52:449-456.

Leaney JL (2003) Contribution of Kir3.1, Kir3.2A and Kir3.2C subunits to native $\mathrm{G}$ protein-gated inwardly rectifying potassium currents in cultured hippocampal neurons. Eur J Neurosci 18:2110-2118.

Leaney JL, Tinker A (2000) The role of members of the pertussis toxinsensitive family of $\mathrm{G}$ proteins in coupling receptors to the activation of the $\mathrm{G}$ protein-gated inwardly rectifying potassium channel. Proc Natl Acad Sci USA 97:5651-5656.

Lee K-H, Ryu CJ, Hong HJ, Kim J, Lee EH (2005) cDNA microarray analysis of nerve growth factor-regulated gene expression profile in rat PC12 cells. Neurochem Res 30:533-540.

Lee MA, Cai L, Hubner N, Lee YA, Lindpaintner K (1997) Tissue- and development-specific expression of multiple alternatively spliced transcripts of rat neuronal nitric oxide synthase. J Clin Invest 100:1507-1512.

Lee NH, Malek RL (1998) Nerve growth factor regulation of m4 muscarinic receptor mRNA stability but not gene transcription requires mitogenactivated protein kinase activity. J Biol Chem 273:22317-22325.

Leyte A, Barr FA, Kehlenbach RH, Huttner WB (1992) Multiple trimeric G-proteins on the trans-Golgi network exert stimulatory and inhibitory effects on secretory vesicle formation. EMBO J 11:4795-4804.

Liste I, Bernard V, Bloch B (2002) Acute and chronic acetylcholinesterase inhibition regulates in vivo the localization and abundance of muscarinic receptors $\mathrm{m} 2$ and $\mathrm{m} 4$ at the cell surface and in the cytoplasm of striatal neurons. Mol Cell Neurosci 20:244-256.

Logothetis DE, Kurachi Y, Galper J, Neer EJ, Clapham DE (1987) The $\beta \gamma$ subunits of GTP-binding proteins activate the muscarinic $\mathrm{K}^{+}$channel in heart. Nature 325:321-326.

Lunn ML, Nassirpour R, Arrabit C, McLeod I, Aires CM, Sawchenko PE, Yates III JR, Slesinger PA (2006) A novel PDZ-containing protein, sorting nexin 27, regulates Kir3 channels. Biophys J [Abstr] 90:832.

Lüscher C, Jan LY, Stoffel M, Malenka RC, Nicoll RA (1997) G-proteincoupled inwardly rectifying $\mathrm{K}^{+}$channels (GIRKs) mediate postsynaptic, but not presynaptic transmitter actions in hippocampal neurons. Neuron 19:687-695.

Ma D, Zerangue N, Raab-Graham K, Fried SR, Jan YN, Jan LY (2002) Diverse trafficking patterns due to multiple traffic motifs in $G$ proteinactivated inwardly rectifying potassium channels from brain and heart. Neuron 33:715-729.

Mitrovic I, Margeta-Mitrovic M, Bader S, Stoffel M, Jan LY, Basbaum AI (2003) Contribution of GIRK2-mediated postsynaptic signaling to opi- ate and alpha 2-adrenergic analgesia and analgesic sex differences. Proc Natl Acad Sci USA 100:271-276.

Morgan AD, Carroll ME, Loth AK, Stoffel M, Wickman K (2003) Decreased cocaine self-administration in Kir3 potassium channel subunit knockout mice. Neuropsychopharmacology 28:932-938.

Mutneja M, Berton F, Suen K-F, Luscher C, Slesinger PA (2005) Endogenous RGS proteins enhance acute desensitization of GABAB receptoractivated GIRK currents in HEK-293T cells. Pflügers Arch 450:61-73.

Pei Q, Lewis L, Grahame-Smith DG, Zetterstrom TSC (1999) Alteration in expression of G-protein-activated inward rectifier $\mathrm{K}^{+}$-channel subunits GIRK 1 and GIRK 2 in the rat brain following electroconvulsive shock. Neuroscience 90:621-627.

Pinkas-Kramarski R, Stein R, Lindenboim L, Sokolovsky M (1992) Growth factor-like effects mediated by muscarinic receptors in PC12M1 cells. J Neurochem 59:2158-2166.

Pondugula SR, Raveendran NN, Ergonul Z, Deng Y, Chen J, Sanneman JD, Palmer LG, Marcus DC (2006) Glucocorticoid regulation of genes in the amiloride-sensitive sodium transport pathway by semicircular canal duct epithelium of neonatal rat. Physiol Genomics 24:114-123.

Reuveny E, Slesinger PA, Inglese J, Morales JM, Iniguez-Lluhi JA, Lefkowitz RJ, Bourne HR, Jan YN, Jan LY (1994) Activation of the cloned muscarinic potassium channel by $\mathrm{G}$ protein $\beta \gamma$ subunits. Nature 370:143-146.

Rishal I, Keren-Raifman T, Yakubovich D, Ivanina T, Dessauer CW, Slepak VZ, Dascal N (2003) $\mathrm{Na}^{+}$promotes the dissociation between Galpha GDP and $\mathrm{G} \beta \gamma$, activating $\mathrm{G}$ protein-gated $\mathrm{K}^{+}$channels. J Biol Chem 278:3840-3845.

Roseberry AG, Bunemann M, Elavunkal J, Hosey MM (2001) Agonistdependent delivery of M2 muscarinic acetylcholine receptors to the cell surface after pertussis toxin treatment. Mol Pharmacol 59:1256-1268.

Rousell J, Haddad E-B, Lindsay MA, Barnes PJ (1997) Regulation of m2 muscarinic receptor gene expression by platelet-derived growth factor: involvement of extracellular signal-regulated protein kinases in the down-regulation process. Mol Pharmacol 52:966-973.

Samsonovich AV, Ascoli GA (2006) Morphological homeostasis in cortical dendrites. Proc Natl Acad Sci USA 103:1569-1574.

Shi H, Wang H, Wang Z (1999) M3 muscarinic receptor activation of a delayed rectifier potassium current in canine atrial myocytes. Life Sci 64:PL251-PL257.

Shui Z, Yamanushi TT, Boyett MR (2001) Evidence of involvement of GIRK1/GIRK4 in long-term desensitization of cardiac muscarinic $\mathrm{K}^{+}$ channels. Am J Physiol Heart Circ Physiol 280:H2554-H2562.

Signorini S, Liao YJ, Duncan SA, Jan LY, Stoffel M (1997) Normal cerebellar development but susceptibility to seizures in mice lacking G proteincoupled, inwardly rectifying $\mathrm{K}^{+}$channel GIRK2. Proc Natl Acad Sci USA 94:923-927.

Slesinger PA, Reuveny E, Jan YN, Jan LY (1995) Identification of structural elements involved in $\mathrm{G}$ protein gating of the GIRK1 potassium channel. Neuron 15:1145-1156.

Slesinger PA, Patil N, Liao YJ, Jan YN, Jan LY, Cox DR (1996) Functional effects of the mouse weaver mutation on $G$ protein-gated inwardly rectifying $\mathrm{K}^{+}$channels. Neuron 16:321-331.

Vaudry D, Stork PJS, Lazarovici P, Eiden LE (2002) Signaling pathways for PC12 cell differentiation: making the right connections. Science 296:1648-1649.

Volpicelli LA, Lah JJ, Levey AI (2001) Rab5-dependent trafficking of the m4 muscarinic acetylcholine receptor to the plasma membrane, early endosomes, and multivesicular bodies. J Biol Chem 276:47590-47598.

Waelbroeck M, Tastenoy M, Camus J, Christophe J (1990) Binding of selective antagonists to four muscarinic receptors (M1 to M4) in rat forebrain. Mol Pharmacol 38:267-273.

Wu H, Nash JE, Zamorano P, Garner CC (2002) Interaction of SAP97 with minus-end-directed actin motor myosin VI. Implications for AMPA receptor trafficking. J Biol Chem 277:30928-30934.

Wuller S, Wiesner B, Loffler A, Furkert J, Krause G, Hermosilla R, Schaefer M, Schulein R, Rosenthal W, Oksche A (2004) Pharmacochaperones posttranslationally enhance cell surface expression by increasing conformational stability of wild-type and mutant vasopressin V2 receptors. J Biol Chem 279:47254-47263.

Yamada M, Inanobe A, Kurachi Y (1998) G protein regulation of potassium ion channels. Pharmacol Rev 50:723-757.

Zheng JQ, Felder M, Connor JA, Poo MM (1994) Turning of nerve growth cones induced by neurotransmitters. Nature 368:140-144. 